\title{
Microstructural Degradation of Ni/YSZ Electrodes in Solid Oxide Electrolysis Cells under High Current
}

Chen, Ming; Liu, Yi-Lin; Bentzen, Janet Jonna; Zhang, Wei; Sun, Xiufu; Hauch, Anne; Tao, Youkun; Bowen, Jacob R.; Hendriksen, Peter Vang

Published in:

Journal of the Electrochemical Society

Link to article, DOI:

$10.1149 / 2.098308$ jes

Publication date:

2013

Document Version

Peer reviewed version

Link back to DTU Orbit

Citation $(A P A)$ :

Chen, M., Liu, Y-L., Bentzen, J. J., Zhang, W., Sun, X., Hauch, A., Tao, Y., Bowen, J. R., \& Hendriksen, P. V. (2013). Microstructural Degradation of Ni/YSZ Electrodes in Solid Oxide Electrolysis Cells under High Current. Journal of the Electrochemical Society, 160(8), F883-F891. https://doi.org/10.1149/2.098308jes

\section{General rights}

Copyright and moral rights for the publications made accessible in the public portal are retained by the authors and/or other copyright owners and it is a condition of accessing publications that users recognise and abide by the legal requirements associated with these rights.

- Users may download and print one copy of any publication from the public portal for the purpose of private study or research.

- You may not further distribute the material or use it for any profit-making activity or commercial gain

- You may freely distribute the URL identifying the publication in the public portal 


\title{
Microstructural degradation of Ni/YSZ electrodes in solid oxide electrolysis cells under high current
}

Ming Chen *, Yi-Lin Liu, Janet Jonna Bentzen, Wei Zhang, Xiufu Sun, Anne Hauch, Youkun Tao, Jacob R. Bowen, Peter Vang Hendriksen

Department of Energy Conversion and Storage, Technical University of Denmark, DK-4000 Roskilde, Denmark

*minc@dtu.dk

\begin{abstract}
$\mathrm{Ni} / \mathrm{yttria}$ stabilized zirconia (YSZ) supported solid oxide electrolysis cells (SOECs) were exposed to long-term galvanostatic electrolysis tests, under different testing conditions (temperature, gas composition, current density etc.) with an emphasis on high current density (above $-1 \mathrm{~A} / \mathrm{cm}^{2}$ ). Detailed post-mortem characterizations were carried out to investigate microstructural changes after long-term galvanostatic tests, focusing on the Ni/YSZ electrode. Formation of $\mathrm{ZrO}_{2}$ nano-particles on $\mathrm{Ni}$ surfaces was observed in cells exposed to -1 or $-1.5 \mathrm{~A} / \mathrm{cm}^{2}$ at 800 or $850{ }^{\circ} \mathrm{C}$, but not in those tested at current densities below $-0.75 \mathrm{~A} / \mathrm{cm}^{2}$. The formation of $\mathrm{ZrO}_{2}$ nano-particles deteriorates $\mathrm{Ni}$ percolation and presumably decreases the number of active triple phase boundaries (TPBs) and is therefore considered a degradation phenomenon. It is hypothesized that the degradation of the $\mathrm{Ni}$ surface is a result of Ni-YSZ interfacial reactions, taking place under the conditions prevailing under strong polarization. A mechanism for the formation of $\mathrm{ZrO}_{2}$ nano-particles on the Ni surface
\end{abstract}


under the electrolysis cell testing is proposed and the possibility of Ni-YSZ interfacial reactions under such conditions $\left(T, p\left(\mathrm{O}_{2}\right)\right)$ is further elucidated by thermodynamic calculations.

\section{Introduction}

Over the past decade, there has been an increased interest in development of solid oxide electrolysis technology for hydrogen or synthesis gas $\left(\mathrm{CO}+\mathrm{H}_{2}\right)$ production. In solid oxide electrolysis cells (SOECs), electrical energy can be converted to chemical energy and stored as $\mathrm{H}_{2}$ or synthesis gas via high temperature electrolysis of steam or co-electrolysis of steam and $\mathrm{CO}_{2}[1,2]$. For SOECs to become commercially interesting, durability is one of the critical issues. Long-term stability for 510 years of operation is generally required $[3,4]$. In addition, it is advantageous to operate SOECs at high current density in order to decrease production cost and to achieve high $\mathrm{H}_{2}$ or synthesis gas production rate.

Several studies of long-term durability of SOECs have been reported in literature and different degradation mechanisms have been observed [2, 5-7]. The suggested degradation mechanisms include segregation of impurity phases (from raw materials or from sealing materials) to the triple phase boundary (TPB) [5], poisoning of Ni/yttria stabilized zirconia (YSZ) electrodes by impurities from the gas stream [2], and oxygen electrode delamination or crack formation within the YSZ electrolyte due to high oxygen activity at the electrolyte-oxygen electrode interface [6]. For SOECs

operated at low current density (below $-1 \mathrm{~A} / \mathrm{cm}^{2}$ ), it has been reported that impurity poisoning of the Ni/YSZ electrode is the main cause for degradation. By cleaning inlet gas to the Ni/YSZ electrode and using alternative seals with minimum emission, almost zero degradation has been demonstrated [8]. At current densities above $-1 \mathrm{~A} / \mathrm{cm}^{2}$, oxygen electrode delaminates or lateral 
cracks form within the YSZ electrolyte, causing an additional, rather severe and irreversible degradation process [6]. On the other hand, the Ni/YSZ electrode degradation was ascribed to a consequence of absorbed impurities, but no direct relation with the applied current density was reported. It is likely that the electrode polarization and the established $p\left(\mathrm{O}_{2}\right)$ at the electrodes is a more determining parameter for the degradation. However, this is not a controlled quantity and is not known accurately in all cases. Hence, results are here grouped according to current density.

In the present work, we present results on post-mortem analysis of Ni/YSZ electrodes exposed to long-term galvanostatic electrolysis tests, under different testing conditions (temperature, gas composition, current density etc.) with the emphasis on high current density (above $-1 \mathrm{~A} / \mathrm{cm}^{2}$ ). The temperature of operation was 800 or $850{ }^{\circ} \mathrm{C}$. Detailed post-mortem characterizations utilizing scanning electron microscopy (SEM) and energy dispersive X-ray spectroscopy (EDS) were carried out to investigate microstructural changes after long-term durability tests. A new degradation mechanism of the Ni/YSZ electrode is reported, which interprets the observed dependence of the microstructural changes on the current density, or more precisely, the electrode over-potential. Thermodynamic calculations were carried out to further elucidate the suggested mechanism.

\section{Experimental}

\section{Electrochemical testing}

Table 1 summarizes the cell test conditions. Except for the Ref2 cell, all the other studied cells (A1A8 and Ref1) have a Ni/YSZ support, a Ni/YSZ active electrode (as the cathode in SOEC mode), a YSZ electrolyte and a LSM/YSZ composite oxygen electrode (as the anode; LSM: strontium doped 
lanthanum manganite). The Ref2 cell differs from the others only by having a LSCF/CGO (LSCF: strontium doped lanthanum cobalt ferrite, CGO: gadolinia doped ceria) oxygen electrode with a CGO barrier layer between the electrolyte and the oxygen electrode. The Ref2 cell is acceptable for use as a reference since the focus of the present study is on the Ni/YSZ electrode side. The details of cell fabrication can be found elsewhere [9]. The electrochemical performance of the cells was characterized via single cell testing (A1-A5, A7-A8, Ref1, and Ref2) or stack testing (A6). All the cells were reduced and subjected to initial performance characterization by measuring DC polarization $(\mathrm{i}-\mathrm{V})$ curves and/or AC electrochemical impedance spectra (EIS), then followed by long-term durability tests, but no long-term testing was performed for the two reference cells (Ref1

and Ref2). The long-term tests were carried out under galvanostatic conditions, i.e. constant current density in the range from -0.5 to $-1.5 \mathrm{~A} / \mathrm{cm}^{2}$. Both steam electrolysis $\left(50 \% \mathrm{H}_{2} \mathrm{O}+50 \% \mathrm{H}_{2}\right)$ and coelectrolysis of steam and $\mathrm{CO}_{2}\left(45 \% \mathrm{CO}_{2}+45 \% \mathrm{H}_{2} \mathrm{O}+10 \% \mathrm{H}_{2}\right)$, with a gas $\left(\mathrm{H}_{2} \mathrm{O}+\mathrm{CO}_{2}\right)$ conversion from $28 \%$ to $80 \%$ (based on Faraday's law) were investigated.

\section{$\underline{\text { Post mortem analysis }}$}

Both fractured and polished cross-sections were prepared from the studied cells. A Supra 35 scanning electron microscope from Carl Zeiss was used, which is equipped with a field emission gun (FE-SEM) for obtaining high resolution and high contrast specifically in low voltage applications. For chemical analysis the Supra 35 is equipped with an X-ray Energy Dispersive Spectrometer (EDS) and a microanalysis software NSS (Thermo Fischer Scientific Inc.). To ensure that observed microstructure patterns are representative, at least three locations of each cell were inspected: inlet, middle, and outlet with respect to gas to the Ni/YSZ electrode. For all the longterm tested cells, the observed microstructural changes are more pronounced at the gas inlet and 
middle of the cell than at the outlet. Due to length limitation, SEM results from different locations are presented here only for Cell A4. For all other studied cells, only results from center of the cells are presented.

For the fractured samples a low accelerating voltage of $5 \mathrm{kV}$ was used which allowed direct imaging of the fractured surface without carbon coating. Combined with usage of a short working distance of 4-5 $\mathrm{mm}$, the surface morphology could be examined on a nano-meter scale. With the aim of increasing sensitivity of surface chemical analysis, a low accelerating voltage of $5 \mathrm{kV}$ was applied also for EDS analysis, which resulted in a X-ray penetration depth of around $200 \mathrm{~nm}$. However, it should be kept in mind that EDS results obtained from irregular fractured surfaces have to be interpreted with precautions. They can only be of a qualitative value even in the best case.

The polished cross-section samples were used firstly to examine the percolation of $\mathrm{Ni}$ in the $\mathrm{Ni} / \mathrm{YSZ}$ electrodes. For this purpose no carbon coating was applied and a low-voltage $(<1 \mathrm{kV})$ charge contrast technique [10] and the Inlens secondary electron detector in the SEM were used. The samples were then carbon coated for SEM imaging and EDS analysis at an accelerating voltage of $15 \mathrm{kV}$.

Cell A4 was selected for further study by transmission electron microscopy (TEM). A small piece from the center of the cell was mechanically polished to a thickness of approximately $20 \mu \mathrm{m}$. Final thinning to $<100 \mathrm{~nm}$ thickness was done by focused ion beam (FIB) milling at 10-20 pA probe current using a $1540 \mathrm{XB}$ FIB SEM from Carl Zeiss operated at $30 \mathrm{kV}$. Final polishing in the FIB was performed at $5 \mathrm{kV}$ in order to reduce the amorphous surface layer and Ga-ion implantation. A 
JEM-3000F microscope (JEOL, Japan) equipped with a field-emission gun operated at $300 \mathrm{kV}$ was employed for high-resolution TEM (HRTEM) analysis. The point resolution of the TEM is $0.19 \mathrm{~nm}$.

\section{Results}

\section{$\underline{\text { Cell degradation }}$}

Details on the performance, durability, and degradation of the cells are reported in [5, 11-13]. Figure 1 presents a plot of cell voltage evolution with time during long-term galvanostatic testing. Among the eight long-term tested cells, Cells A5, A7 and A8 were tested applying steam electrolysis at $850{ }^{\circ} \mathrm{C}$ and -1.5 or $-0.5 \mathrm{~A} / \mathrm{cm}^{2}$, while the other five cells were tested applying coelectrolysis of steam and $\mathrm{CO}_{2}$ at a temperature of 800 or $850{ }^{\circ} \mathrm{C}$ and a current density of $-0.75,-1$ or $-1.5 \mathrm{~A} / \mathrm{cm}^{2}$. For Cell A6, which is one of the eleven cells tested in a stack [11], the measured voltage represents the contribution over an entire single repeating unit (SRU, including cell, interconnect, and contact between the cell and interconnect). The interconnect plate contact resistance was reported to be around $0.10 \Omega \mathrm{cm}^{2}\left(800{ }^{\circ} \mathrm{C}\right)$, corresponding to a voltage loss of $75 \mathrm{mV}$ at $-0.75 \mathrm{~A} / \mathrm{cm}^{2}$. The actual cell voltage will therefore be about $75 \mathrm{mV}$ lower than the measured SRU voltage. The OCV and final cell voltage for the eight tested cells are further listed in Table 1. The

cell over-potential at the end of electrolysis testing is then calculated as "Final cell voltage - OCV" and also given in Table 1. For Cell A6, two values are provided: one over the SRU (actually measured) and the other corrected for the interconnect plate contact resistance. At the end of the durability tests, the cells reached a voltage ranging from $1116 \mathrm{mV}$ (A8) to $1772 \mathrm{mV}$ (A1), corresponding to a cell over-potential ranging from $161 \mathrm{mV}$ (A8) to $900 \mathrm{mV}$ (A1). 
$\underline{\text { SEM observations }}$

In the present work, both the fractured and polished cross-sections of the cells were examined using SEM and EDS, with a focus on the active Ni/YSZ electrode. Due to a large number of cells to be examined, a careful selection of the cells for different post-mortem characterization schemes (fractured or polished cross-sections) was carried out. The fractured cross-section is ideal for investigating morphology changes of $\mathrm{Ni}$ or YSZ grains, while the polished one is more suitable for investigating Ni percolation and for EDS analysis. A short summary of main findings from postmortem characterizations of the Ni/YSZ electrodes is listed in Table 2.

\section{Fractured surfaces}

The fractured surfaces of the three tested cells A3, A4, and A8 as well as a reference cell Ref2 were examined. Cells A2 $\left(-1.5 \mathrm{~A} / \mathrm{cm}^{2}, 800{ }^{\circ} \mathrm{C}\right)$ and $\mathrm{A} 3\left(-1.5 \mathrm{~A} / \mathrm{cm}^{2}, 800{ }^{\circ} \mathrm{C}\right)$ were tested under the same conditions for almost same period of time. The two cells show similar microstructure degradation pattern. Also the cells showed very similar electrical degradation pointing to a good reproducibility of the results. In this paper, only the SEM results from Cell A3 are presented. Figure 2 shows details of the active Ni/YSZ electrode microstructure at different magnifications. High resolution SEM of the fractured surfaces revealed nano-particles covering a major part of the Ni grains closest to the interface between the Ni/YSZ active electrode and the YSZ electrolyte in Cells A3 (-1.5 $\left.\mathrm{A} / \mathrm{cm}^{2}, 800{ }^{\circ} \mathrm{C}\right)$ and $\mathrm{A} 4\left(-1 \mathrm{~A} / \mathrm{cm}^{2}, 850{ }^{\circ} \mathrm{C}\right)$, being more pronounced in Cell A4. As illustrated in Figures $2 b-d$, the formation of nano-particles was a general feature over the entire cell for Cell A4, though the abundance of the nano-particles differs among the three inspected locations, being more abundant at the inlet and center than at the outlet. This is also true for the other long-term tested 
cells at $-1.5 \mathrm{~A} / \mathrm{cm}^{2}$ (such as Cell A3). Here only the SEM image from the center is presented (Figure 2a) due to space limitation. The size of these particles varies from around 10 to $100 \mathrm{~nm}$. These nano-particles appear on the Ni grain surface, which was originally in contact with pores, or YSZ grains, or other $\mathrm{Ni}$ grains. In the two latter cases, the formation of these nano-particles will obviously introduce detachment of Ni-Ni or Ni-YSZ interface. This type of nano-particles was not found on the Ni grains farther away from the interface and in the support. For the cells tested at -0.5 $\mathrm{A} / \mathrm{cm}^{2}$ (A7 and A8) and Cell Ref2, formation of nano-particles on Ni grains was not found.

Figure 3 shows EDS point analyses on Ni and YSZ grain surfaces in Cell A4 $\left(-1 \mathrm{~A} / \mathrm{cm}^{2}, 850{ }^{\circ} \mathrm{C}\right)$ and Cell Ref2. With a working distance of $13 \mathrm{~mm}$ for EDS analysis and an accelerating voltage of 5 $\mathrm{kV}$, the signal intensity (i.e. the signal-to-noise ratio) is rather low. However, qualitatively the EDS point analyses provide the information that the nano-particles (Point 3 in Figure 3a) contain high amounts of $\mathrm{Zr}$ and $\mathrm{O}$, indicating that these nano-particles might be $\mathrm{Zr}$-oxide. Note that in the reference cell (Cell Ref2), individual particles can be clearly identified as either YSZ or Ni. "Effectively" intermediate compositions like Point 3 in Figure 3a are not observed in Cell Ref2.

In addition, TEM analysis of Cell A4 has confirmed that these nano-particles (as illustrated by the arrows in Figure $4 \mathrm{a}$ ) are $\mathrm{Y}$-containing $\mathrm{ZrO}_{2}$. Figures $4 \mathrm{~b}$ and $4 \mathrm{c}$ show two representative HRTEM images, corresponding to the yellow and cyan circled areas in Figure 4a. By measuring the interplanar lattice spacing of local areas in the inverse Fast Fourier Transform (IFFT) images (Figures $4 \mathrm{~b}$ and $4 \mathrm{c}$ insets) where characteristic crystal planes of cubic or tetragonal $\mathrm{ZrO}_{2}$ phases are well identified, one can confirm that the nano-particles are cubic or tetragonal zirconia. Figure $4 \mathrm{~d}$ further gives EDS point analysis of the characteristic areas: Points 1, 2 and 3 in Figure 4a, corresponding to bulk YSZ, Ni-YSZ interface, Ni-pore interface respectively. A variety of Zr/Y atomic ratios from 
the bulk YSZ $(\mathrm{Zr} / \mathrm{Y}=4.3)$ to the Ni-YSZ (2.8) or Ni-pore (6.4) interface was detected, indicating a mechanism of dissolution - diffusion - exsolution or precipitation accounting for the formation of the $\mathrm{ZrO}_{2}$ nano-particles.

\section{Polished surfaces}

Polished samples of the cells A1 $\left(-1.5 \mathrm{~A} / \mathrm{cm}^{2}, 800{ }^{\circ} \mathrm{C}\right), \mathrm{A} 5\left(-1.5 \mathrm{~A} / \mathrm{cm}^{2}, 850{ }^{\circ} \mathrm{C}\right), \mathrm{A} 6\left(-0.75 \mathrm{~A} / \mathrm{cm}^{2}\right.$, $800{ }^{\circ} \mathrm{C}$ ) and Ref1 were examined initially for evaluating Ni percolation. In the images obtained by the low-voltage contrast technique (Figure 5), significant loss of $\mathrm{Ni}$ percolation in the active electrode can be seen in the first two cells A1 and A5 as compared with the reference cell, whereas the Ni percolation in the active electrode is practically intact for the cell A6 tested at $-0.75 \mathrm{~A} / \mathrm{cm}^{2}$ (Figure 5c).

In the SEM image of a polished cross-section, the Ni grain surfaces in contact with pores, or YSZ grains or other Ni grains are displayed as Ni-pore, Ni-YSZ or Ni-Ni interfaces, respectively. Therefore, variations of these interfaces observed in the polished sample of tested cells are indications of microstructural changes occurred on the surface of $\mathrm{Ni}$ grains, which are shown in Figure 6. It appears that in Cell A1 $\left(-1.5 \mathrm{~A} / \mathrm{cm}^{2}, 800{ }^{\circ} \mathrm{C}\right)$ and Cell A5 $\left(-1.5 \mathrm{~A} / \mathrm{cm}^{2}, 850{ }^{\circ} \mathrm{C}\right)$, new interfacial phases or gaps of a hundred nm or less in thickness are formed, which look like dark rings (continuous or discontinuous) around $\mathrm{Ni}$ (Figure 6a and b). In some cases a narrow region of a collection of nano-particles can be seen at Ni interfaces (Figure 6b). On the other hand, the Ni

interface in Cells A6 $\left(-0.75 \mathrm{~A} / \mathrm{cm}^{2}, 800{ }^{\circ} \mathrm{C}\right)$ and $\mathrm{A} 8\left(-0.5 \mathrm{~A} / \mathrm{cm}^{2}, 850{ }^{\circ} \mathrm{C}\right)$ is practically as clean as that in the reference cell Ref1 (Figure 6e). In addition to changes at the interface, inclusions inside Ni grains were found in Cell A5, which appear as black dots in Figure 6b. 
Figure 7 shows a SEM image and EDS line-scan crossing an interfacial region containing nanoparticles between two Ni particles in Cell A5 $\left(-1.5 \mathrm{~A} / \mathrm{cm}^{2}, 850{ }^{\circ} \mathrm{C}\right)$. The line-scan profile shows that the interface region contains $\mathrm{Zr}, \mathrm{O}$ and very little $\mathrm{Y}$ (close to the detection limit for SEM/EDS) besides Ni. It has to be noted that the object is too small (the interface region is less than $0.5 \mu \mathrm{m}$ in width) for a proper quantitative EDS analysis. However, the line-scan results do yield qualitative information indicating that the nano-particles on the surface of $\mathrm{Ni}$ are $\mathrm{Zr}$-oxide particles.

EDS point analysis was also performed in the interior of relatively large Ni grains (with a diameter of at least $1 \mu \mathrm{m})$ in the active Ni/YSZ electrode. Typical results are given in Table 3. Substantial concentrations of $\mathrm{Zr}$ and $\mathrm{Si}$ are detected within the $\mathrm{Ni}$ grains in the active layer. The Si content decreases sharply with increasing distance (up to 2-3 $\mu \mathrm{m}$ ) from the interface with the electrolyte while no significant changes of the $\mathrm{Zr}$ content are found within these few microns. As shown in Figure $6 \mathrm{~b}$ and Figure $7 \mathrm{a}$, Si-oxide precipitates as dark round spots (100 nm or less) within the Ni grains which are close to the electrode-electrolyte interface. The EDS line-scan (Figure 7b) evidences that the dark spot contains Si and O.

The SEM observations on the fractured and polished samples analyzed in this work are largely consistent with each other: In the active Ni/YSZ electrode, 1) nano-particles are formed on the surface of Ni grains in contact with YSZ grains, or other Ni grains, or pores, and 2) these nanoparticles contain $\mathrm{Zr}$ and O, i.e. Zr-oxide. SEM observations shown in Figure 6 further reveal that the interface variations are more significant in the cells tested at higher current density (equal to or above $-1 \mathrm{~A} / \mathrm{cm}^{2}$, such as in Cell A1/A2/A3/A4/A5) than at lower current density (below $-1 \mathrm{~A} / \mathrm{cm}^{2}$, such as in Cell A6/A7/A8), suggesting that these interfacial reactions are associated with the 
electrochemical processes during ageing. These variations are also more significant for the cells tested for longer time and/or at higher temperature (Cell A4: $-1 \mathrm{~A} / \mathrm{cm}^{2}, 850{ }^{\circ} \mathrm{C}$ and Cell $\mathrm{A} 5:-1.5$ $\left.\mathrm{A} / \mathrm{cm}^{2}, 850{ }^{\circ} \mathrm{C}\right)$. The SEM observations strongly suggest that formation of nano-particles on $\mathrm{Ni}$ surfaces is a degradation process of the Ni/YSZ electrode. Because it introduces detachment of Ni$\mathrm{Ni}$ and Ni-YSZ interfaces, weakens or blocks the electric contact between Ni grains or between Ni and YSZ grains, deteriorates $\mathrm{Ni}$ percolation and presumably decreases active TPB. Similar phenomena were recently reported by Tietz et al. [14]. They carried out detailed post-mortem characterizations on a Ni/YSZ electrode supported cell operated for steam electrolysis at $800{ }^{\circ} \mathrm{C}$ and $-1 \mathrm{~A} / \mathrm{cm}^{2}$ for 9000 hours. Formation of nano-particles on Ni surfaces in the active Ni/YSZ electrode is clearly shown in Figure $8 \mathrm{a}$ of their paper. However, no detailed account of the underlying mechanism is shown.

\section{Discussion}

$\underline{\text { Mechanism for formation of } \mathrm{ZrO}_{2}} \underline{\text { nano-particles }}$

Electrochemically induced $\mathrm{ZrO}_{2}$ reduction at the $\mathrm{Ni}-\mathrm{ZrO}_{2}$ interface has been previously reported [15-17]. At very low oxygen partial pressures the $\mathrm{Ni}^{-} \mathrm{ZrO}_{2}$ interface is thermodynamically unstable. Therefore, intermetallic phases NixZry may form at the interface under low oxygen activity. On the other hand, $\mathrm{Ni}_{x} \mathrm{Zr}_{\mathrm{y}}$ may be oxidized forming $\mathrm{Ni}$ and $\mathrm{ZrO}_{2}$ at the interface with high oxygen activity. This type of process occurs at very low oxygen partial pressure (see below) and is not realistic under the present cell test condition.

In the present work we hypothesize a slightly different mechanism which is illustrated in Figure 8. During SOEC testing, the over-potential at the Ni-YSZ interface results in a local interface region 
with a decreased oxygen partial pressure, under which Zr atoms at the Ni-YSZ interface start to dissolve into the metallic Ni phase. The Zr then diffuses via the bulk or surface of Ni (Figure 8, green dashed lines) and precipitates as $\mathrm{ZrO}_{2}$ somewhere else where $\mu\left(\mathrm{O}_{2}\right)$ (or $\left.p\left(\mathrm{O}_{2}\right)\right)$ is higher and the chemical potential of $\mathrm{Zr}-\mu(\mathrm{Zr})$ is lower, for example, at the interface between $\mathrm{Ni}-\mathrm{Ni}$ or between Ni-pore. Though we have no evidence to exclude diffusion of $\mathrm{Zr}$ via the Ni grain surface, it is most likely that $\mathrm{ZrO}_{2}$ nano-particles formed at the Ni-Ni or Ni-pore interface were induced by $\mathrm{Zr}$ bulk diffusion through $\mathrm{Ni}$.

Thermodynamics of Ni-Zr-O

In this work, thermodynamic calculations were carried out to further elucidate the proposed mechanism. To calculate the reactions at the Ni-YSZ interface, a thermodynamic database of Ni-Y$\mathrm{Zr}-\mathrm{O}$ is required which is still under development by the present authors. Instead, a semiquantitative discussion based on thermodynamic calculations of the Ni-Zr-O system using FACTSAGE Thermochemical Software and Databases [18] is presented here.

The calculations are based on thermodynamics of $\mathrm{NiO}$, cubic $\mathrm{ZrO}_{2}$, and the metallic phases in Ni-Zr. Eight intermetallic compounds $\left(\mathrm{Ni}_{5} \mathrm{Zr}, \mathrm{Ni}_{7} \mathrm{Zr}_{2}, \mathrm{Ni}_{3} \mathrm{Zr}_{2}, \mathrm{Ni}_{21} \mathrm{Zr}_{8}, \mathrm{Ni}_{4} \mathrm{Zr}_{3}, \mathrm{Ni}_{11} \mathrm{Zr}_{9}, \mathrm{NiZr}\right.$, and $\mathrm{NiZr}_{2}$ ) exist in the Ni-Zr system. Besides, the metallic Ni phase (FCC) can dissolve less than 2 mol.\% Zr. However, there is no experimental evidence to confirm a particular value. Metallic Zr has two polymorphs, a low temperature HCP phase with almost zero Ni solubility and a high temperature BCC phase with a few mole percent $\mathrm{Ni}$ solubility. The interaction between $\mathrm{NiO}$ and $\mathrm{ZrO}_{2}$ is rather limited. No complex oxide exists in the $\mathrm{NiO}-\mathrm{ZrO}_{2}$ system. A few studies have been carried out to examine the solubility of $\mathrm{NiO}$ in $\mathrm{ZrO}_{2}$ and a solubility limit of from 2 to $20 \mathrm{~mol} . \% \mathrm{NiO}$ in cubic or 
tetragonal $\mathrm{ZrO}_{2}$ was reported by different groups [19-21]. The discrepancy could be partially attributed to the fact that stabilization of $\mathrm{ZrO}_{2}$ depends on its surface to volume ratio [22], i.e. below the critical particle size for monoclinic $\mathrm{ZrO}_{2}$ formation, tetragonal or cubic $\mathrm{ZrO}_{2}$ can be stabilized. However, high temperature treatment may still destabilize tetragonal or cubic $\mathrm{ZrO}_{2}$. The above mentioned studies may just represent a picture of metastable equilibrium in $\mathrm{NiO}-\mathrm{ZrO}_{2}$. It is still questionable if $\mathrm{NiO}$ alone can actually stabilize tetragonal or cubic $\mathrm{ZrO}_{2}$ at high temperature without any other dopant such as $\mathrm{Y}_{2} \mathrm{O}_{3}$. The solubility of $\mathrm{ZrO}_{2}$ in $\mathrm{NiO}$ was reported to be negligible at $1600{ }^{\circ} \mathrm{C}$ by Chang et al. [23]. In this work, no interaction between $\mathrm{NiO}$ and $\mathrm{ZrO}_{2}$ is considered.

Figures 9 and 10 present phase diagrams of $\mathrm{Ni}-\mathrm{Zr}-\mathrm{O}_{2}$ at $850^{\circ} \mathrm{C}$. According to the calculations, with decreasing oxygen partial pressure at the $\mathrm{Ni}-\mathrm{ZrO}_{2}$ interface, $\mathrm{Zr}$ from $\mathrm{ZrO}_{2}$ starts to dissolve into metallic Ni. To estimate at which $p\left(\mathrm{O}_{2}\right)$ this process occurs, a limiting $\mathrm{Zr}$ content in the metallic Ni phase needs to be specified. The equilibrium oxygen partial pressure can then be back calculated. Here $1 \mathrm{ppm}$ of $\mathrm{Zr}$ in the metallic Ni phase was assumed as the limiting content. This translates into an equilibrium oxygen partial pressure of $3.2 \times 10^{-29}$ bar. When the oxygen partial pressure is below $3.2 \times 10^{-29}$ bar, the equilibrium concentration of $\mathrm{Zr}$ in metallic $\mathrm{Ni}$ is higher than $1 \mathrm{ppm}$. This can be further expressed as the reaction below:

$$
\mathrm{ZrO}_{2}(\text { cubic })+\mathrm{Ni}(\mathrm{fcc})=1 \mathrm{ppmZr} \mathrm{r}_{\mathrm{In} \mathrm{Ni}}(\mathrm{fcc})+\mathrm{O}_{2} \text { (gas) }(1)
$$

It is reasonable to assume that the process of $\mathrm{Zr}$ dissolving into $\mathrm{Ni}$ at the $\mathrm{Ni}-\mathrm{ZrO}_{2}$ interface starts at a $p\left(\mathrm{O}_{2}\right)$ equal to or lower than $3.2 \times 10^{-29}$ bar. With decreasing oxygen partial pressure, the solubility of $\mathrm{Zr}$ in $\mathrm{Ni}$ increases and reaches a maximum of $0.5 \mathrm{~mol} . \%$ at $850^{\circ} \mathrm{C}$. The dissolved $\mathrm{Zr}$ may further diffuse and precipitate somewhere else where $p\left(\mathrm{O}_{2}\right)$ is higher and form $\mathrm{ZrO}_{2}$. The 
oxygen solubility in $\mathrm{Ni}$ is rather small, below $0.05 \mathrm{~mol} \%$ which is only one tenth of the maximum $\mathrm{Zr}$ solubility in $\mathrm{Ni}$ [24]. The kinetics of $\mathrm{Zr}$ diffusion in $\mathrm{Ni}$ is yet unknown. However, a rough idea can still be obtained by using the kinetics of $\mathrm{Hf}$ diffusion in Ni. The intrinsic diffusivity of $\mathrm{Hf}$ in $\mathrm{Ni}$ has been measured to be in the order of $10^{-12} \mathrm{~cm}^{2} / \mathrm{s}$ at $850^{\circ} \mathrm{C}$ [25], corresponding to a diffusion distance of $\sim 1 \mu \mathrm{m}$ in one hour. The kinetics of oxygen diffusion in $\mathrm{Ni}$ is much faster than that of $\mathrm{Zr}$ and is in the order of $10^{-9} \mathrm{~cm}^{2} / \mathrm{s}$ at $850^{\circ} \mathrm{C}$ [26], corresponding to a diffusion distance of $\sim 40 \mu \mathrm{m}$ in one hour. It is reasonable to assume that $\mathrm{ZrO}_{2}$ will most probably precipitate at the Ni-Ni or Ni-pore interface, though a possibility of $\mathrm{ZrO}_{2}$ precipitation inside $\mathrm{Ni}$ grains cannot be totally ruled out.

As shown in Figure 9, at $p\left(\mathrm{O}_{2}\right) \leq 10^{-33}$ bar, various intermetallic compounds form at the $\mathrm{Ni}-\mathrm{ZrO}_{2}$ interface, in equilibrium with metallic $\mathrm{Ni}$ on one side and $\mathrm{ZrO}_{2}$ on the other. The reaction for formation of $\mathrm{Ni}_{5} \mathrm{Zr}$ can be written as:

$$
\mathrm{ZrO}_{2}(\text { cubic })+5 \mathrm{Ni}(\mathrm{fcc})=\mathrm{Ni}_{5} \mathrm{Zr}+\mathrm{O}_{2}(\text { gas })(2)
$$

This process corresponds to the observations reported by Wagner et al. [15-16] and Klotz et al. [17]. When $p\left(\mathrm{O}_{2}\right)$ is below $1.3 \times 10^{-41}$ bar, $\mathrm{ZrO}_{2}$ is no longer stable and is reduced into metallic $\mathrm{Zr}$ (hcp).

$$
\mathrm{ZrO}_{2}(\text { cubic })=\mathrm{Zr}(\text { hcp })+\mathrm{O}_{2}(\text { gas })(3)
$$

Based on the above calculations, it is clear that stability of $\mathrm{ZrO}_{2}$ in contact with $\mathrm{Ni}$ is strongly reduced as compared to pure $\mathrm{ZrO}_{2}$, i.e. the reduction $p\left(\mathrm{O}_{2}\right)$ of $\mathrm{ZrO}_{2}$ is increased from $1.3 \times 10^{-41}$ bar (pure $\left.\mathrm{ZrO}_{2}\right)$ to $3.2 \times 10^{-29}$ bar $\left(\mathrm{ZrO}_{2}\right.$ in contact with $\mathrm{Ni}$ ). 
It should be emphasized that the thermodynamics for Reactions (1) and (2) has not been experimentally validated. The reliability of the calculated critical $p\left(\mathrm{O}_{2}\right)$ for the above calculations relies on the reliability of the Gibbs energy functions. A difference of $50 \mathrm{~kJ} / \mathrm{mol}$ in the Gibbs energy, which is within a normal uncertainty range for measured enthalpy, can result in a difference of 3 decades in the calculated critical $p\left(\mathrm{O}_{2}\right)$. For example, Wagner et al. [16] claimed that Reaction (2) takes place at $10^{-27}$ bar at $1200 \mathrm{~K}$, while FACTSAGE gives $10^{-30}$ bar. The calculated critical $p\left(\mathrm{O}_{2}\right)$ in the present work shall therefore be interpreted bearing in mind this uncertainty, such as $3.2 \times 10^{-}$ ${ }^{29 \pm 3}$ bar for Reaction (1) at $850{ }^{\circ} \mathrm{C}$.

With respect to influence of yttrium, the solubility of yttrium in $\mathrm{Ni}$ was reported to be $0.1 \mathrm{~mol} \%$ at $1523 \mathrm{~K}$ and effectively zero at lower temperature [27]. NiO and $\mathrm{Y}_{2} \mathrm{O}_{3}$ do not react with each other and the mutual solubility is negligible. According to the thermodynamics of the Y-Zr-O system, the presence of yttria in YSZ at the Ni-YSZ interface may have some influence on the Zr dissolving process, but not in a significant way. The above calculations can be applied to the Ni-YSZ interface fairly well. However, a validated thermodynamic database of Ni-Y-Zr-O is still valuable in order to clarify the reactions at the Ni-YSZ interface.

\section{Over-potential at the Ni-YSZ interface}

In this section we analyze the over-potential at the Ni-YSZ interface to see if it is likely that conditions that predict $\mathrm{Zr}$ reduction are reached. 
According to the Nernst equation, the oxygen partial pressure at the Ni-YSZ interface in an operating SOEC cell is determined by local gas composition and over-potential (voltage loss between OCV and cell voltage under current) over the Ni-YSZ interface:

$$
\left.\eta_{\mathrm{Ni} / \mathrm{YSZ}}=\mathrm{R} \times T \times \ln \left(p\left(\mathrm{O}_{2}\right)_{\text {Local gas }}\right) / p\left(\mathrm{O}_{2}\right)_{\mathrm{Ni} / \mathrm{YSZ}}\right) /(4 \times \mathrm{F})(4)
$$

Where $\mathrm{R}$ is the gas constant and F is Faraday's constant. This is further illustrated in Figure 11. Here over-potential is used for discussion instead of $p\left(\mathrm{O}_{2}\right)$, in order to be better correlated with measured cell voltages. As for Cell A5 $\left(-1.5 \mathrm{~A} / \mathrm{cm}^{2}, 850{ }^{\circ} \mathrm{C}\right.$, Figure 11a), in order to reach a critical $p\left(\mathrm{O}_{2}\right)$ of $3.2 \times 10^{-29 \pm 3}$ bar at the Ni-YSZ interface, an over-potential of $625 \pm 167 \mathrm{mV}$ is required with reference to a local gas composition of $50 \% \mathrm{H}_{2} \mathrm{O}+50 \% \mathrm{H}_{2}$ (i.e., no gas conversion, $p\left(\mathrm{O}_{2}\right)=5.3 \times$ $10^{-18}$ bar). Local gas composition changes, which are caused by conversion of steam into hydrogen, can contribute $106 \mathrm{mV}$ at $80 \%$ conversion and $177 \mathrm{mV}$ at $95 \%$ conversion. The remaining shall be contributed by the cathode polarization $-\eta_{\mathrm{Ni} / \mathrm{YSZ}}$, which is estimated from the measured cell voltages in this work. For actual $\eta_{\mathrm{Ni} / \mathrm{YSZ}}$, an average value over the entire cell could be determined by equivalent circuit modeling of the measured impedance spectra, assuming that various electrochemical processes can be well separated. For the cell type (Ni/YSZ cathode, YSZ electrolyte, and LSM/YSZ anode) tested here, the cathode part of the cell resistance is initially $20 \%$ of the total cell resistance for steam electrolysis, $40-50 \%$ for $\mathrm{CO}_{2}$ electrolysis, and in between for co-electrolysis $[5,28,29]$. Hauch et al. reported that the cathode part of the cell resistance was increased from $\sim 20 \%$ of the total cell resistance to $\sim 30 \%$ after $500-1200$ hours testing at $-0.5 \mathrm{~A} / \mathrm{cm}^{2}$ and $850{ }^{\circ} \mathrm{C}$ [5]. In some incidents the degradation at the cathode is much stronger than at the anode [13]. It could be expected that the cathode constitutes a much higher percentage of the total resistance (or the total cell over-potential) after long-term testing at -1 or $1.5 \mathrm{~A} / \mathrm{cm}^{2}$. It is rather 
difficult to determine local $\eta_{\mathrm{Ni} / Y S Z}$, as it is dependent on a number of factors such as local gas composition and local current distribution. In this work, we simply assume the local $\eta_{\mathrm{Ni} / \mathrm{YSZ}}$ to be $1 / 3-2 / 3$ of the total over-potential over the entire cell measured at the end of durability tests. This is at least in specific cases a sound assumption according to previous investigations [5, 13, 28-29].

As shown in Figure 11, if one assumes that $\sim 40 \%$ of the cell over-potential in Cell A5 $\left(-1.5 \mathrm{~A} / \mathrm{cm}^{2}\right.$, $850{ }^{\circ} \mathrm{C}$ ) is due to the $\mathrm{Ni} / \mathrm{YSZ}$ cathode, it is strong enough to lead to reduction of $\mathrm{ZrO}_{2}$ at the $\mathrm{ZrO}_{2^{-}}$ $\mathrm{Ni}$ interface. For Cell A3 $\left(-1.5 \mathrm{~A} / \mathrm{cm}^{2}, 800{ }^{\circ} \mathrm{C}\right)$, one has to assume that $55 \%$ of the total cell overpotential occurs at the cathode to reach the estimated level for the $\mathrm{ZrO}_{2}$ reduction (not shown here). As discussed in the previous paragraph, in some cases, the cathode polarization can indeed constitute such large part of the total cell over-potential, though in general for this type of cell it is not that dominant. For Cells A1 and A2, conditions are similar to A3 and A5. For all these cells formation of $\mathrm{ZrO}_{2}$ nano-particles on $\mathrm{Ni}$ grain surfaces was observed. For the cells where this was not observed (A6-A8), polarizations are much smaller, and the $p\left(\mathrm{O}_{2}\right)$ at the Ni-YSZ interface does not reach the level needed for $\mathrm{ZrO}_{2}$ reduction at the interface.

It is clear that there is a strong correlation between formation of $\mathrm{ZrO}_{2}$ nano-particles and polarization; the $\mathrm{ZrO}_{2}$ nano-particles only formed close to the interface and only in the strongest polarized cells. The semi-quantitative assessment attempted above indicates that in the case of a strong domination of cathode polarization, one can reach sufficiently reducing conditions to reach the level estimated from the calculated phase diagrams. However, the correlation between estimated polarizations and observed microstructural changes is not fully consistent. Cell A4 $\left(-1 \mathrm{~A} / \mathrm{cm}^{2}, 850\right.$ ${ }^{\circ} \mathrm{C}$ ), where also $\mathrm{ZrO}_{2}$ nano-particles were formed, was not polarized to an extent where conditions can reach the predicted threshold. It is suggested that the reason for this lies in an uncertainty of the 
required $p\left(\mathrm{O}_{2}\right)$ for the reduction. An effort to determine reduction potential of $\mathrm{ZrO}_{2}$ on $\mathrm{Ni}$ is underway.

It should be mentioned that the critical $p\left(\mathrm{O}_{2}\right)$ for Reaction (2) is $10^{-33}$ bar at $850{ }^{\circ} \mathrm{C}$, being four decades lower than that for Reaction (1). It is most unlikely that the $p\left(\mathrm{O}_{2}\right)$ at the Ni-YSZ interface in the here tested cells will reach the threshold allowing for Reaction (2) to take place. It is however difficult to totally rule out the possibility due to large uncertainty associated with the thermodynamics.

Also Si can be reduced and dissolved in the $\mathrm{Ni}$ grains in a reaction analogue to Reaction (1). It is well established that silica is present as an impurity in the Ni/YSZ materials $[5,30]$. Besides, $\mathrm{Si}$ from glass seal evaporates in highly humidified atmospheres and is transported via the gas stream in a form of $\mathrm{Si}(\mathrm{OH})_{4}$, and finally deposits at the triple phase boundary of the Ni/YSZ electrode [5]. The minimum over-potential required for $\mathrm{Si}$ from $\mathrm{SiO}_{2}$ dissolving into $\mathrm{Ni}$ at $850{ }^{\circ} \mathrm{C}$ is calculated as $170 \mathrm{mV}$. This is totally realistic for Ni/YSZ electrode under high electrolysis current (see Table 1). After the cell is returned to $\mathrm{OCV}$, the dissolved $\mathrm{Si}$ may be oxidized again as a $\mathrm{SiO}_{2}$ inclusion. This explains the phenomena observed in Cell A5 $\left(-1.5 \mathrm{~A} / \mathrm{cm}^{2}, 850{ }^{\circ} \mathrm{C}\right.$, Figures 5 and 6$)$. In addition, a clear relation between $\mathrm{Si}$ inclusion and distance to the glass seal has been confirmed (not presented in this paper); the closer to the glass seal, the more $\mathrm{SiO}_{2}$ inclusions. This further supports our proposed mechanism.

$\underline{\text { Summary }}$ 
In this work, formation of $\mathrm{ZrO}_{2}$ nano-particles on $\mathrm{Ni}$ grains was observed in the active $\mathrm{Ni} / \mathrm{YSZ}$ electrode, only in the region close to the cathode-electrolyte interface, i.e. where one will find the most reducing conditions in the Ni/YSZ electrode during electrolysis testing. The $\mathrm{ZrO}_{2}$ nanoparticles are observed in cells tested at current density equal to or above $-1 \mathrm{~A} / \mathrm{cm}^{2}$, but not in nontested cells or cells tested at lower current density. The harsher the conditions (in terms of cathode polarization, temperature, and testing period), the larger the abundance of the $\mathrm{ZrO}_{2}$ particles.

It is emphasized that $\mathrm{Zr}$ reduction may occur at a much higher $p\left(\mathrm{O}_{2}\right)$ in the presence of $\mathrm{Ni}$ than when in pure $\mathrm{ZrO}_{2}$ (or YSZ) form. The threshold value is around $3.2 \times 10^{-29 \pm 3}$ bar at $850{ }^{\circ} \mathrm{C}$, assuming an error range of $50 \mathrm{~kJ} / \mathrm{mol}$ for $\Delta G$ of Reaction (1). The observation of a clear correlation with cathode polarization and the observation of a variety of $\mathrm{Zr} / \mathrm{Y}$ ratios from the bulk YSZ to the $\mathrm{ZrO}_{2}$ nano-particles formed at the Ni-YSZ or Ni-pore interface support qualitatively the formulated hypothesis for the formation mechanism being a reduction, followed by solid diffusion and reprecipitation at sites with higher $p\left(\mathrm{O}_{2}\right)$.

However, the correlation between estimated polarizations and observed microstructural changes is not fully consistent. The reason for the discrepancy is ascribed to an uncertainty of the required $p\left(\mathrm{O}_{2}\right)$ for the reduction. It should be noted that considerable uncertainty is associated both with the assessments of local $p\left(\mathrm{O}_{2}\right)$ in the experiments and the calculated thresholds. The predicted $p\left(\mathrm{O}_{2}\right)$ rely on an assumption of how the degradation is distributed over the cell and an assumption that the cathode contributes $40-60 \%$ of the total cell resistance when tested at current density above -1 $\mathrm{A} / \mathrm{cm}^{2}$. This is estimated from other tests but not measured directly on the here tested cells. A large uncertainty however is associated with the thermodynamics of the interface reactions. Firstly this could be inaccurately determined. Secondly its value could be somehow affected by special 
conditions relevant to the tests here. For example, presence of $\mathrm{Si}$ could somehow reduce the $\mathrm{Zr}$ stability or the reduction potential could be affected by Ni particle size or presence of non-identified secondary phases. We are currently trying to measure directly the decomposition potential of $\mathrm{ZrO}_{2}$ on $\mathrm{Ni}$ to obtain a better quantitative assessment of this, which could allow a quantitative proof or disproof of the hypothesis and strengthen the more quantitative arguments presented here.

\section{Conclusions}

This is a report of post-mortem analyses of a number of SOECs tested under both co-electrolysis and steam electrolysis conditions at $800-850^{\circ} \mathrm{C}$ with current density ranging from -0.5 to $-1.5 \mathrm{~A} / \mathrm{cm}^{2}$. An important microstructural degradation of the Ni-YSZ electrode revealed by SEM is the formation of $\mathrm{ZrO}_{2}$ nano-particles on $\mathrm{Ni}$ surfaces, which deteriorates the percolation of $\mathrm{Ni}$ and presumably decreases the number of active TPB. The degradation of Ni surface is a result of NiYSZ interfacial reactions, which are associated with the electrochemical processes and overpotential at the Ni-YSZ interface. A mechanism of how the $\mathrm{ZrO}_{2}$ nano-particles are formed on Ni surfaces during the electrolysis cell testing is proposed. It is postulated that $\mathrm{Zr}$ is reduced at the $\mathrm{Ni}$ YSZ interface, dissolved into $\mathrm{Ni}$ and precipitated as $\mathrm{ZrO}_{2}$ at interfaces with higher $p\left(\mathrm{O}_{2}\right)$. Relevant

Ni-YSZ interfacial reactions and their likelihood under such conditions $\left(T, p\left(\mathrm{O}_{2}\right)\right)$ are further elucidated by thermodynamic calculations.

\section{Acknowledgement}


This work was financially supported by Energinet.dk through the projects ForskEL 2010-1-10432 "planSOEC-R\&D and commercialization roadmap for SOEC electrolysis" and ForskEL 2011-110609 "Development of SOEC cells and stacks".

\section{References}

[1] A. Brisse, J. Schefold, and M. Zahid, Int. J. Hydrogen Energy, 33, 5375 (2008).

[2] S. D. Ebbesen, C. Graves, A. Hauch, S. H. Jensen, and M. Mogensen, J. Electrochem. Soc., 157, B1419 (2010).

[3] Q. X. Fu, C. Mabilat, M. Zahid, A. Brisse, and L. Gautier, Energy Environ. Sci., 3, 1382 (2010).

[4] C. Graves, S. D. Ebbesen, M. Mogensen, and K. S. Lackner, Renewable Sustainable Energy Rev., 15, 1 (2011).

[5] A. Hauch, S. D. Ebbesen, S. H. Jensen, and M. Mogensen, J. Electrochem. Soc., 155, B1184 (2008).

[6] R. Knibbe, M. L. Traulsen, A. Hauch, S. D. Ebbesen, and M. Mogensen, J. Electrochem. Soc., 157, B1209 (2010).

[7] M. A. Laguna-Bercero, R. Campana, A. Larrea, J. A. Kilner, and V. M. Orera, J. Power Sources, 196, 8942 (2011).

[8] S. D. Ebbesen and M. Mogensen, Electrochem. Solid-State Lett., 13, B106 (2010).

[9] A. Hagen, M. Menon, R. Barfod, P. V. Hendriksen, S. Ramousse, and P. H. Larsen, Fuel Cells, 6, $146(2006)$.

[10] K. Thyden, Y. L. Liu, and J. B. Bilde-Sorensen, Solid State Ionics, 178, 1984 (2008).

[11] M. Chen, J. V. T. Høgh, J. U. Nielsen, J. J. Bentzen, S. D. Ebbesen, and P. V. hendriksen, Fuel Cells, accepted, (2013). 
[12] X. Sun, M. Chen, P. Hjalmarsson, S. D. Ebbesen, S. H. Jensen, M. Mogensen, and P. V. Hendriksen, ECS Trans., 41(33), 77 (2012).

[13] P. Hjalmarsson, X. F. Sun, Y. L. Liu, and M. Chen, J. Power Sources, 223, 349 (2013).

[14] F. Tietz, D. Sebold, A. Brisse, and J. Schefold, J. Power Sources, 223, 129 (2013).

[15] T. Wagner, R. Kirchheim, and M. Ruhle, Acta Metall. Mater., 40, S85 (1992).

[16] T. Wagner, G. Duscher, and R. Kirchheim, J. Mater. Res., 14, 3340 (1999).

[17] D. Klotz, B. Butz, A. Leonide, J. Hayd, D. Gerthsen, and E. Ivers-Tiffee, J. Electrochem. Soc., 158, B587 (2011).

[18] C. W. Bale, P. Chartrand, S. A. Degterov, G. Eriksson, K. Hack, R. Ben Mahfoud, J. Melancon, A. D. Pelton, and S. Petersen, Calphad, 26, 189 (2002).

[19] M. K. Dongare, K. Malshe, C. S. Gopinath, I. K. Murwani, and E. Kemnitz, J. Catal., 222, 80 (2004).

[20] G. Dhalenne, B. Bonvalot, A. Revcolevschi, and F. Millot, J. Am. Ceram. Soc., 73, 1524 (1990).

[21] A. C. Bose, R. Ramamoorthy, and S. Ramasamy, Mater. Lett., 44, 203 (2000).

[22] M. W. Pitcher, S. V. Ushakov, A. Navrotsky, B. F. Woodfield, G. S. Li, J. Boerio-Goates, and B. M. Tissue, J. Am. Ceram. Soc., 88, 160 (2005).

[23] W. S. Chang, S. Chen, and P. Shen, Mater. Sci. Eng., A, 145, 113 (1991).

[24] M. Kowalski and P. J. Spencer, Calphad, 19, 229 (1995).

[25] C. E. Campbell, W. J. Boettinger, and U. R. Kattner, Acta Materialia, 50, 775 (2002).

[26] J.-W. Park and C. Altstetter, Metall. Trans. A, 18, 43 (1987).

[27] M. Mezbahul-Islam and M. Medraj, Calphad, 33, 478 (2009).

[28] S. D. Ebbesen, R. Knibbe, and M. Mogensen, J. Electrochem. Soc., 159, F482 (2012).

[29] S. D. Ebbesen and M. Mogensen, ECS Trans., submitted, (2013). 
[30] K. V. Hansen, K. Norrman, and M. Mogensen, Surf. Interface Anal., 38, 911 (2006). 
Table 1 Test conditions of the studied cells [5, 11-13]. Theoretical EMF values at these test conditions are included as well for comparison.

\begin{tabular}{|c|c|c|c|c|c|c|c|c|c|c|c|}
\hline \multirow{2}{*}{$\begin{array}{l}\text { Cell ID in the } \\
\text { present work }\end{array}$} & \multirow[t]{2}{*}{ Test type } & \multicolumn{10}{|c|}{ Conditions for galvanostic durability tests } \\
\hline & & $\begin{array}{l}\text { Tem } \\
\text { p. } \\
\left({ }^{\circ} \mathrm{C}\right)\end{array}$ & $\begin{array}{l}\text { Gas } \\
\text { composition } \\
\text { (to } \mathrm{Ni} / \mathrm{YSZ} \text { ) }\end{array}$ & $\begin{array}{l}\text { Current } \\
\text { density } \\
\left(\mathbf{A} / \mathbf{c m}^{2}\right)\end{array}$ & $\begin{array}{l}\text { Gas } \\
\left(\mathrm{CO}_{2}+\mathrm{H}_{2} \mathrm{O}\right) \\
\text { conversion } \\
(\%)\end{array}$ & $\begin{array}{l}\text { Testing } \\
\text { period } \\
\text { (hour) }\end{array}$ & $\begin{array}{l}\text { Theoretic } \\
\text { al EMF } \\
(\mathrm{mV})\end{array}$ & $\begin{array}{l}\text { Measur } \\
\text { ed OCV } \\
(\mathrm{mV})\end{array}$ & $\begin{array}{l}\text { Final } \\
\text { cell } \\
\text { voltage } \\
{ }^{\text {a }(\mathrm{mV})}\end{array}$ & $\begin{array}{l}\text { Final cell } \\
\text { over- } \\
\text { potential }^{\mathrm{a}} \\
(\mathrm{mV})\end{array}$ & $\begin{array}{l}\Delta \mathrm{V}^{\mathrm{b}} \\
(\mathrm{mV})\end{array}$ \\
\hline A1 & Durability & 800 & $\begin{array}{l}\mathrm{CO}_{2} / \mathrm{H}_{2} \mathrm{O} / \mathrm{H}_{2} \\
(45 / 45 / 10)\end{array}$ & -1.5 & $62 \%$ & 312 & 874 & 872 & 1772 & 900 & 300 \\
\hline A2 & Durability & 800 & $\begin{array}{l}\mathrm{CO}_{2} / \mathrm{H}_{2} \mathrm{O} / \mathrm{H}_{2} \\
(45 / 45 / 10)\end{array}$ & -1.5 & $62 \%$ & 584 & 874 & 870 & 1703 & 833 & 242 \\
\hline A3 & Durability & 800 & $\begin{array}{l}\mathrm{CO}_{2} / \mathrm{H}_{2} \mathrm{O} / \mathrm{H}_{2} \\
(45 / 45 / 10)\end{array}$ & -1.5 & $62 \%$ & 526 & 874 & 870 & 1694 & 824 & 265 \\
\hline A4 & Durability & 850 & $\begin{array}{l}\mathrm{CO}_{2} / \mathrm{H}_{2} \mathrm{O} / \mathrm{H}_{2} \\
(45 / 45 / 10)\end{array}$ & -1 & $62 \%$ & 1256 & 853 & 863 & 1283 & 420 & 153 \\
\hline A5 & Durability & 850 & $\begin{array}{l}\mathrm{H}_{2} / \mathrm{H}_{2} \mathrm{O} \\
(50 / 50)\end{array}$ & -1.5 & $80 \%$ & 890 & 962 & 961 & 1873 & 912 & 413 \\
\hline A6 & Durability & 800 & $\begin{array}{l}\mathrm{CO}_{2} / \mathrm{H}_{2} \mathrm{O} / \mathrm{H}_{2} \\
(45 / 45 / 10)\end{array}$ & -0.75 & $60 \%$ & 1005 & 874 & 875 & $\begin{array}{l}1204^{\mathrm{c}} \\
1129^{\mathrm{d}}\end{array}$ & $\begin{array}{l}329^{\mathrm{c}} \\
254^{\mathrm{d}}\end{array}$ & -118 \\
\hline A7 & Durability & 850 & $\begin{array}{l}\mathrm{H}_{2} / \mathrm{H}_{2} \mathrm{O} \\
(50 / 50) \\
\end{array}$ & -0.5 & $28 \%$ & 1316 & 962 & 953 & 1175 & 222 & 32 \\
\hline A8 & Durability & 850 & $\begin{array}{l}\mathrm{H}_{2} / \mathrm{H}_{2} \mathrm{O} \\
(50 / 50)\end{array}$ & -0.5 & $28 \%$ & 1510 & 962 & 955 & 1116 & 161 & 41 \\
\hline Ref1 & \multicolumn{11}{|c|}{ Only initial performance characterization, no durability test. } \\
\hline Ref2 & \multicolumn{11}{|c|}{ Only initial performance characterization, no durability test. } \\
\hline
\end{tabular}


Table 2 Summary of main findings from post-mortem characterizations of the Ni/YSZ electrodes

\begin{tabular}{|c|c|c|c|c|c|c|}
\hline \multirow{2}{*}{$\begin{array}{l}\text { Cell ID in } \\
\text { the present } \\
\text { work }\end{array}$} & \multicolumn{3}{|c|}{ Conditions for galvanostic durability tests } & \multirow{2}{*}{$\begin{array}{l}\text { Fractured surface } \\
\text { Number of } \mathrm{ZrO}_{2} \text { nano-particles } \\
\text { per Ni grain }\end{array}$} & \multicolumn{2}{|l|}{ Polished surface } \\
\hline & $\begin{array}{l}\text { Current } \\
\text { density } \\
\left(\mathrm{A} / \mathbf{c m}^{2}\right)\end{array}$ & $\begin{array}{l}\text { Temp. } \\
\left({ }^{\circ} \mathrm{C}\right)\end{array}$ & $\begin{array}{l}\text { Final cell over- } \\
\text { potential }^{\text {a }}(\mathrm{mV})\end{array}$ & & $\begin{array}{l}\text { Loss of } \mathrm{Ni} \\
\text { percolation }\end{array}$ & $\begin{array}{l}\text { Formation of gaps or } \\
\text { new phases at the Ni- } \\
\mathrm{Ni} \text { or Ni-YSZ } \\
\text { interface }\end{array}$ \\
\hline A1 & -1.5 & 800 & 900 & (Not examined) & Severe & Yes \\
\hline $\mathrm{A} 2$ & -1.5 & 800 & 833 & Up to a few tens & (Not examined) & Yes \\
\hline A3 & -1.5 & 800 & 824 & Up to a few tens & (Not examined) & Yes \\
\hline A4 & -1 & 850 & 420 & Up to a few hundred & (Not examined) & Yes \\
\hline A5 & -1.5 & 850 & 912 & (Not examined) & Most severe & Yes \\
\hline A6 & -0.75 & 800 & $\begin{array}{l}329^{\mathrm{b}} \\
254^{\mathrm{c}}\end{array}$ & (Not examined) & Minor & No \\
\hline A7 & -0.5 & 850 & 222 & 0 & (Not examined) & No \\
\hline A8 & -0.5 & 850 & 161 & 0 & (Not examined) & No \\
\hline Ref1 & & & & (Not examined) & Negligible & No \\
\hline $\operatorname{Ref} 2$ & & & & 0 & (Not examined) & No \\
\hline
\end{tabular}

${ }^{\mathrm{a}}$ Measured at the end of the durability tests at the conditions for the long-term testing.

${ }^{\mathrm{b}}$ Over the entire SRU (single repeat unit).

${ }^{\mathrm{c}}$ Over the cell, i.e. corrected with voltage loss due to interconnect plate contact resistance (about $75 \mathrm{mV}$ ). 
Table 3 EDS point analysis within $\mathrm{Ni}$ in the active Ni/YSZ electrode layer in Cell A5 $\left(-1.5 \mathrm{~A} / \mathrm{cm}^{2}\right.$, $850{ }^{\circ} \mathrm{C}$ ).

\begin{tabular}{|c|c|c|}
\hline & Zr, at. $\%$ & $\mathrm{Si}$, at. $\%$ \\
\hline $\begin{array}{l}\mathrm{Ni} \text { grains at the electrode- } \\
\text { electrolyte interface }\end{array}$ & & \\
\hline No. 1 & 3.7 & 3.8 \\
\hline No. 2 & 5.8 & 3.8 \\
\hline No. 3 & 3.7 & 1.8 \\
\hline No. 4 & 2.8 & 2.0 \\
\hline $\begin{array}{l}\mathrm{Ni} \text { grains } 2-3 \mu \mathrm{m} \text { from the } \\
\text { interface }\end{array}$ & & \\
\hline No. 1 & 5.9 & $\sim 0$ \\
\hline No. 2 & 1.7 & 0.7 \\
\hline No. 3 & 3.7 & $\sim 0$ \\
\hline No. 4 & 2.9 & $\sim 0$ \\
\hline
\end{tabular}




\section{Figure captions:}

Figure 1 Development of the cell voltages with time under galvanostatic conditions. The detailed test conditions are listed in Table 1. The voltage fluctuation for Cell A1 within the first 70 hours was caused by unstable steam supply, which was later resolved for the remaining test period. The voltage for Cell A6 was measured over the SRU (single repeat unit, including cell, interconnect, and contact between the cell and interconnect). The actual cell voltage is about $75 \mathrm{mV}$ lower than the measured SRU voltage.

Figure 2 Fracture surface of (a) Cell A3 (-1.5 A/ $\left.\mathrm{cm}^{2}, 800{ }^{\circ} \mathrm{C}\right),(\mathrm{b}),(\mathrm{c})$, and (d) of Cell A4 (-1 A/cm ${ }^{2}$, $850{ }^{\circ} \mathrm{C}$ ) showing nano-particles formed on the surface of Ni grains right at the interface with the electrolyte, (e) Cell A8 $\left(-0.5 \mathrm{~A} / \mathrm{cm}^{2}, 850{ }^{\circ} \mathrm{C}\right)$ and (f) Cell Ref2 showing the surface of Ni grains is free of nano-particles. For Cell A4, the SEM images were taken from the inlet (Figure 2b), center (Figure 2c), and outlet (Figure 2d), respectively. For all the other cells, the images presented were taken from the center.

Figure 3 EDS point analyses on Ni and YSZ grain surfaces of the fractured samples from a) Cell A4 $\left(-1 \mathrm{~A} / \mathrm{cm}^{2}, 850{ }^{\circ} \mathrm{C}\right)$ and b) Cell Ref2. The results show qualitatively that the nano-particles observed in Cell A4 contain $\mathrm{Zr}$ and $\mathrm{O}$.

Figure 4 (a) TEM image showing morphology of the Ni-YSZ interface in Cell A4. (b) and (c) HRTEM images of the circled areas of nano-particles. The insets are the enlarged local IFFT images. (d) EDS point analysis of the characteristic areas of Points 1-3 in Figure 4a.

Figure 5 SEM images showing Ni percolation in the active Ni/YSZ electrode and in the support layer (a) Cell A1 $\left(-1.5 \mathrm{~A} / \mathrm{cm}^{2}, 800{ }^{\circ} \mathrm{C}\right)$, (b) Cell A5 $\left(-1.5 \mathrm{~A} / \mathrm{cm}^{2}, 850{ }^{\circ} \mathrm{C}\right)$, (c) Cell A6 $\left(-0.75 \mathrm{~A} / \mathrm{cm}^{2}\right.$, $\left.800{ }^{\circ} \mathrm{C}\right)$ and $(\mathrm{d})$ Cell Ref1.

Figure 6 SEM images of the active Ni/YSZ electrode (a) Cell A1 $\left(-1.5 \mathrm{~A} / \mathrm{cm}^{2}, 800{ }^{\circ} \mathrm{C}\right)$, (b) Cell A5 $\left(-1.5 \mathrm{~A} / \mathrm{cm}^{2}, 850{ }^{\circ} \mathrm{C}\right)$, (c) Cell A6 $\left(-0.75 \mathrm{~A} / \mathrm{cm}^{2}, 800{ }^{\circ} \mathrm{C}\right)$, (d) Cell A8 $\left(-0.5 \mathrm{~A} / \mathrm{cm}^{2}, 850{ }^{\circ} \mathrm{C}\right)$, and (e) Cell Ref1.

Figure 7 (a) SEM image and (b) EDS linescan of Cell A5 $\left(-1.5 \mathrm{~A} / \mathrm{cm}^{2}, 850{ }^{\circ} \mathrm{C}\right)$.

Figure 8 Schematic illustration of the mechanism for formation of $\mathrm{ZrO}_{2}$ nano-particles on $\mathrm{Ni}$ surfaces.

Figure 9 Phase diagram of $\mathrm{Ni}-\mathrm{Zr}-\mathrm{O}_{2}$ at $850{ }^{\circ} \mathrm{C}$.

Figure 10 Ni-rich part of Ni-Zr- $\mathrm{O}_{2}$ phase diagram at $850{ }^{\circ} \mathrm{C}$.

Figure 11 Over-potential of the Ni-YSZ interface, (a) Cell A5 $\left(-1.5 \mathrm{~A} / \mathrm{cm}^{2}, 850{ }^{\circ} \mathrm{C}\right)$, (b) Cell A8 ($\left.0.5 \mathrm{~A} / \mathrm{cm}^{2}, 850{ }^{\circ} \mathrm{C}\right)$. In each figure, the $p\left(\mathrm{O}_{2}\right)$ value at the bottom corresponds to that of gas at zero conversion, while the three $p\left(\mathrm{O}_{2}\right)$ values at the top correspond to $p\left(\mathrm{O}_{2}\right)$ ranges for Reaction (1). 
$\begin{array}{lllllll}0 & 0 & 0 & 0 & 0 & 0 & 0 \\ 0 & 0 & 0 & 0 & 0 & 0\end{array}$

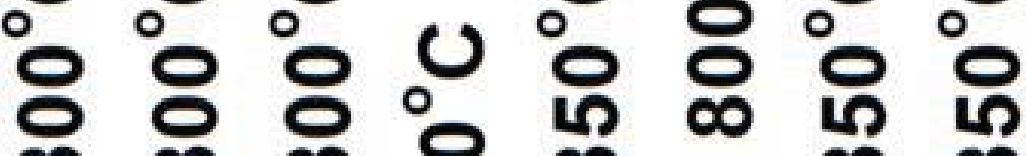

$\infty \infty \infty \Gamma_{n} \infty{ }_{n} \infty \infty$

$n=n n^{n} n^{n} \infty n^{n} n^{n} n^{n} n^{n}$

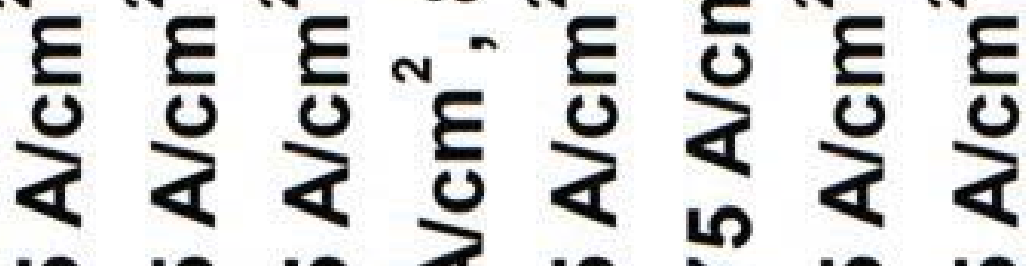

10 ம

†

$\ddot{\sigma} \ddot{\sim} \ddot{\dot{v}} \ddot{\dot{v}} \ddot{\sim} \ddot{\sim}$ $\varangle<<<<<<<$

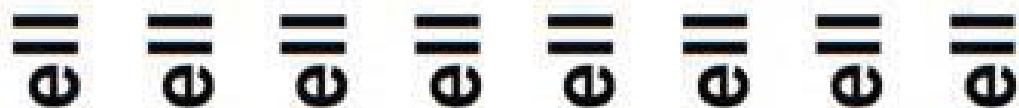

৩ U U U U U U U
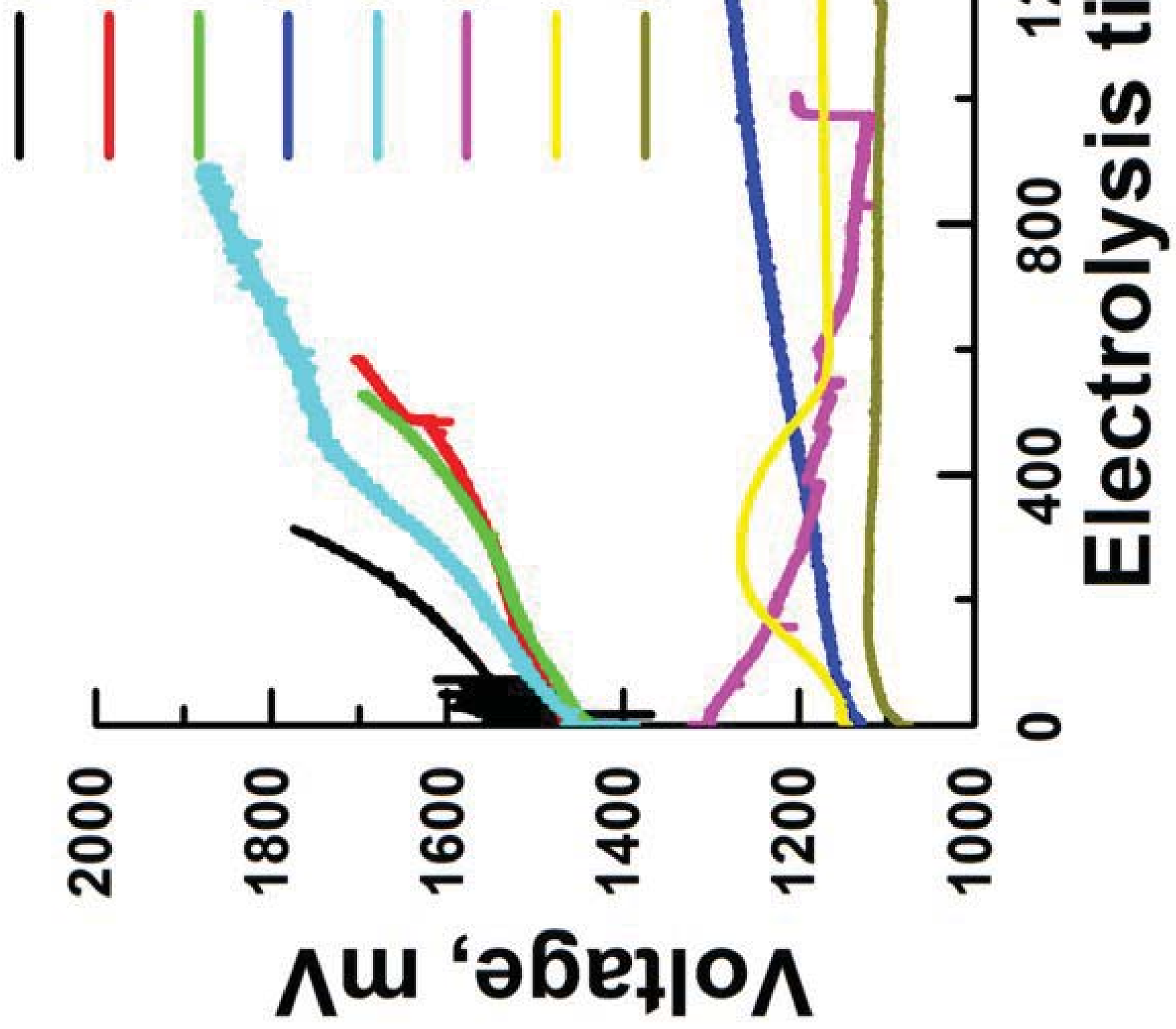


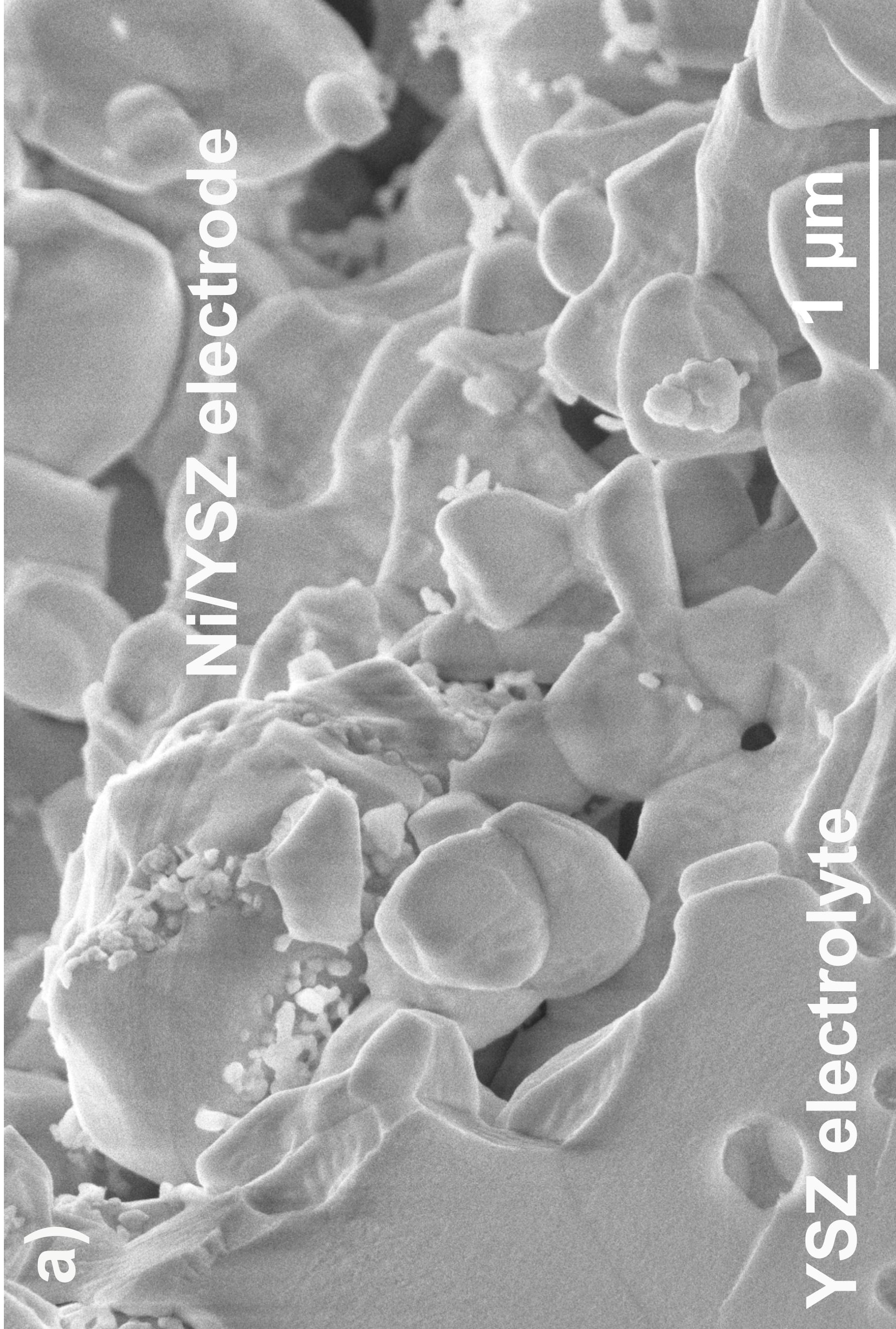




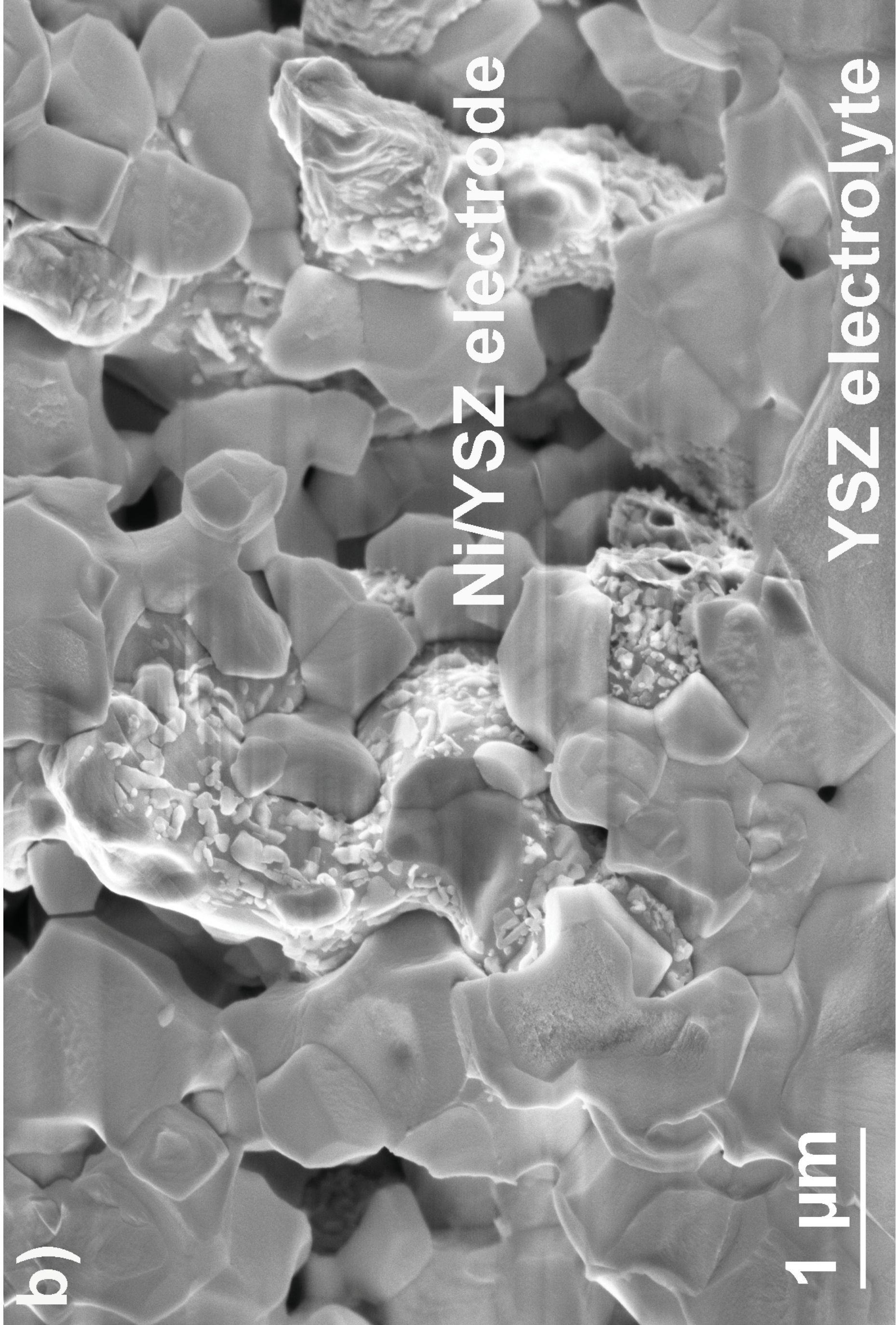




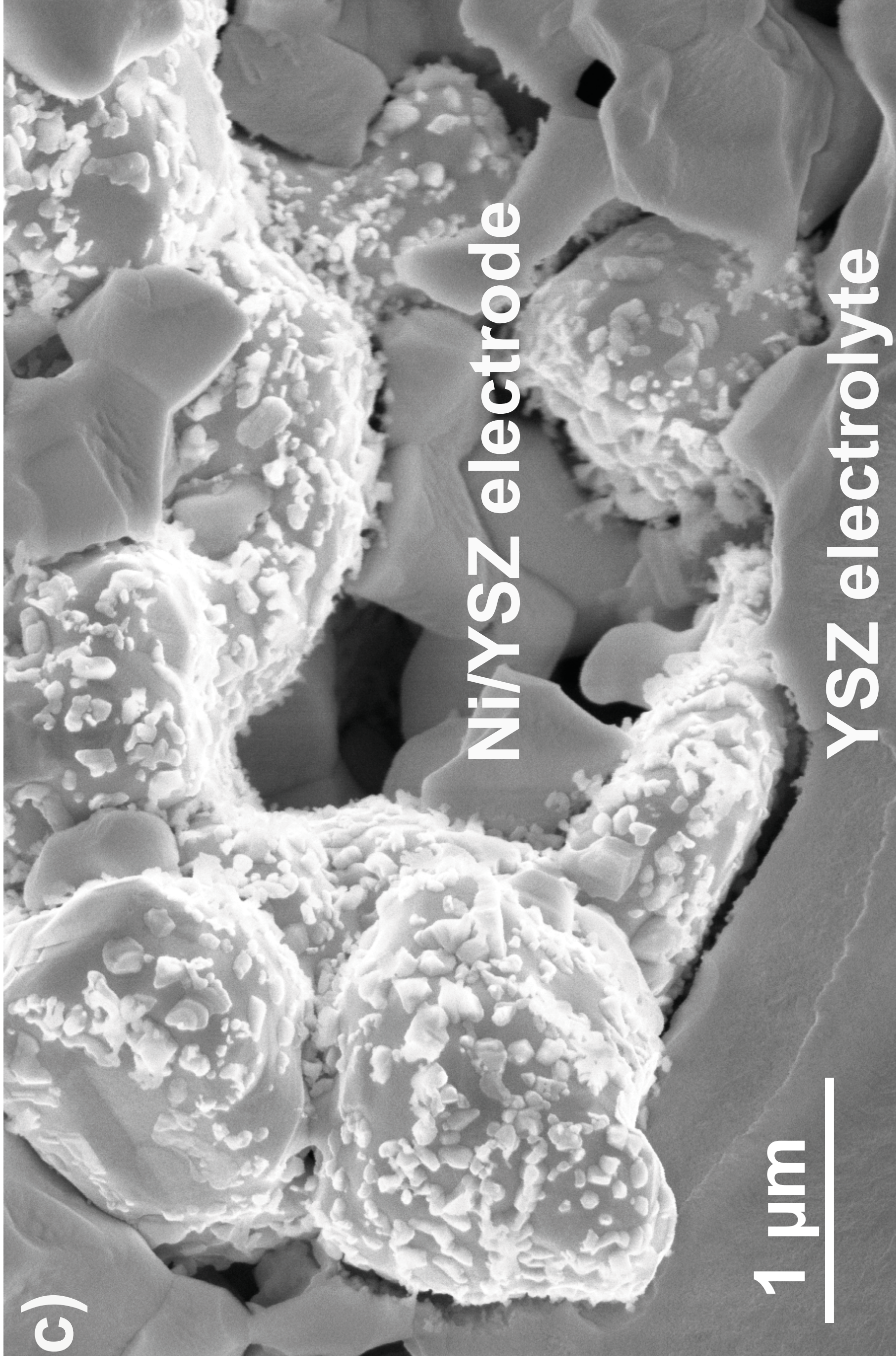




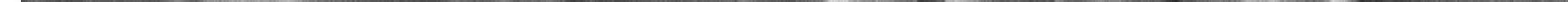




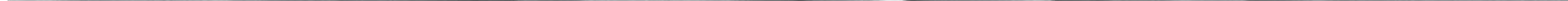




\section{YSZ electrolyte}

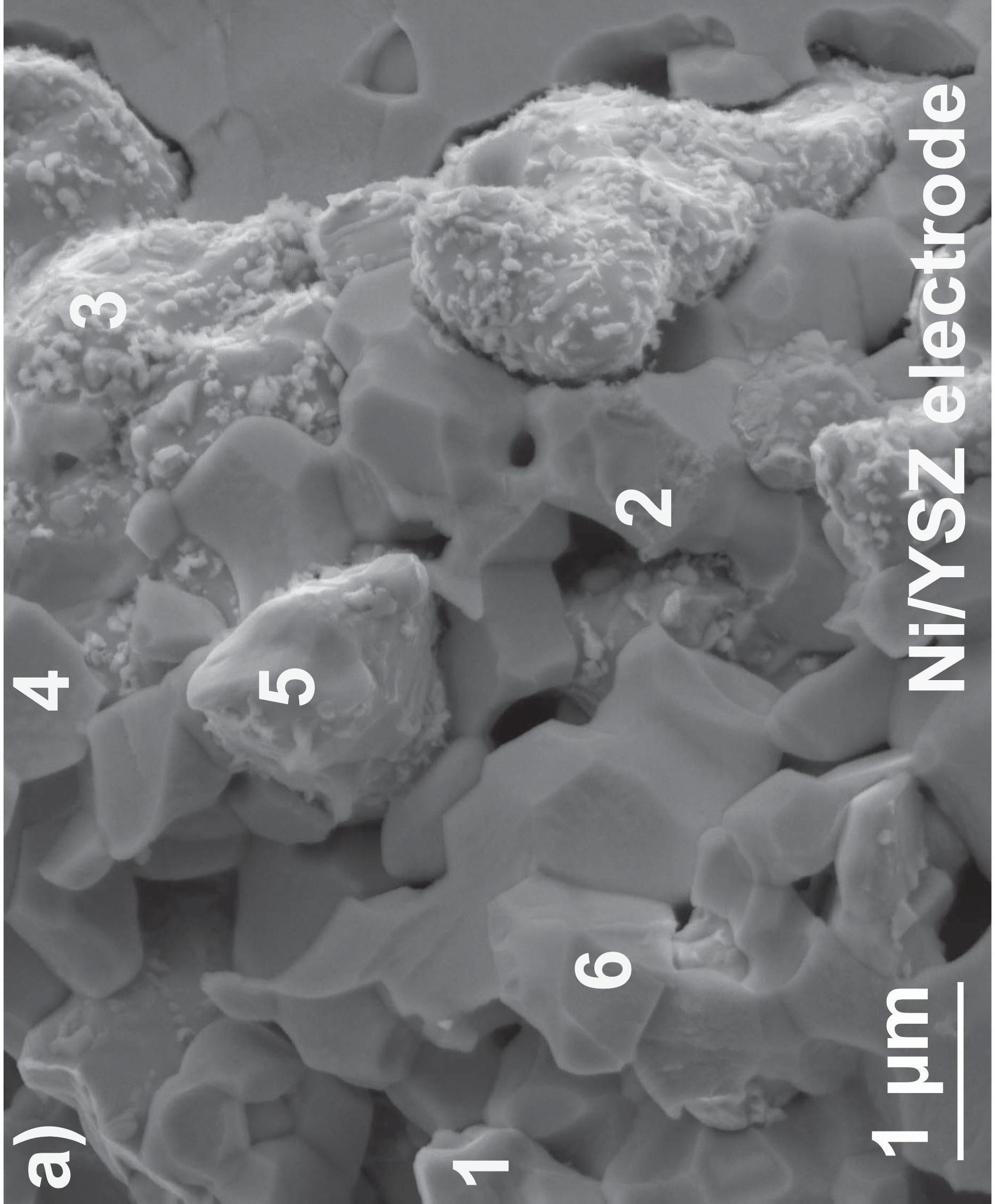




\begin{tabular}{|l|l|l|l|l|l|}
\hline & $\mathrm{O}$, at.\% & $\mathrm{Ni}$ & $\mathrm{Y}$ & $\mathrm{Zr}$ & $\mathrm{Hf}$ \\
\hline Point 1 & 6.4 & 92.5 & 0.0 & 1.0 & 0.1 \\
\hline Point 2 & 65.2 & 0.6 & 5.9 & 27.8 & 0.5 \\
\hline Point 3 & 29.1 & 57.2 & 2.2 & 11.5 & 0.0 \\
\hline Point 4 & 62.6 & 1.8 & 6.3 & 28.9 & 0.4 \\
\hline Point 5 & 9.6 & 87.5 & 0.7 & 2.2 & 0.0 \\
\hline Point 6 & 68.1 & 0.7 & 5.6 & 25.4 & 0.2 \\
\hline
\end{tabular}




\begin{tabular}{|l|l|l|l|l|l|}
\hline & $\mathrm{O}$, at.\% & $\mathrm{Ni}$ & $\mathrm{Y}$ & $\mathrm{Zr}$ & $\mathrm{Hf}$ \\
\hline Point 1 & 10.3 & 87.4 & 0.3 & 1.9 & 0.1 \\
\hline Point 2 & 7.0 & 91.7 & 0.3 & 0.7 & 0.3 \\
\hline Point 3 & 73.0 & 0.0 & 5.6 & 21.1 & 0.3 \\
\hline Point 4 & 64.5 & 0.0 & 5.0 & 30.3 & 0.2 \\
\hline
\end{tabular}


(1)

YSZ

(2)

$200 \mathrm{~nm}$

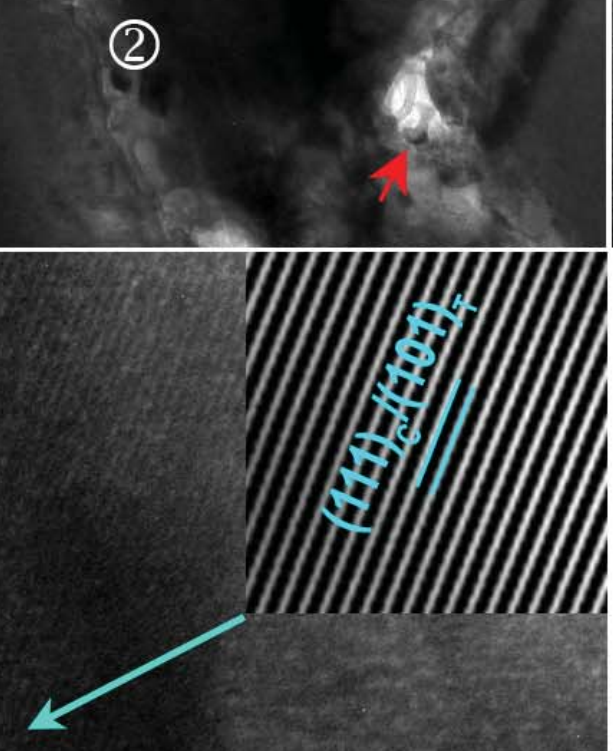

$5 \mathrm{~nm}$

d

\begin{tabular}{cccc}
\hline & Ni, cation\% & $\mathrm{Y}$ & $\mathrm{Zr}$ \\
\hline Point (1) & 2.1 & 18.4 & 79.5 \\
\hline Point (2) & 15.9 & 22.0 & 62.1 \\
\hline Point (3) & 9.9 & 12.2 & 77.9 \\
\hline
\end{tabular}

\section{$5 \mathrm{~nm}$}




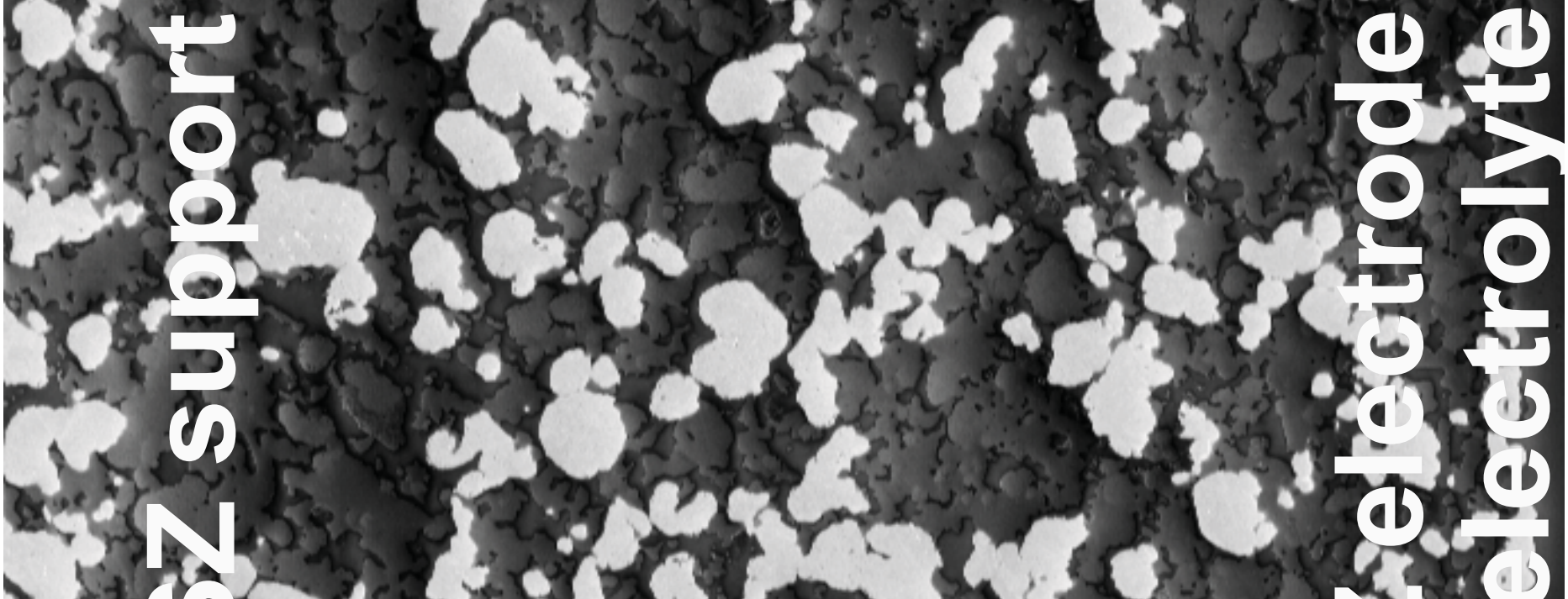

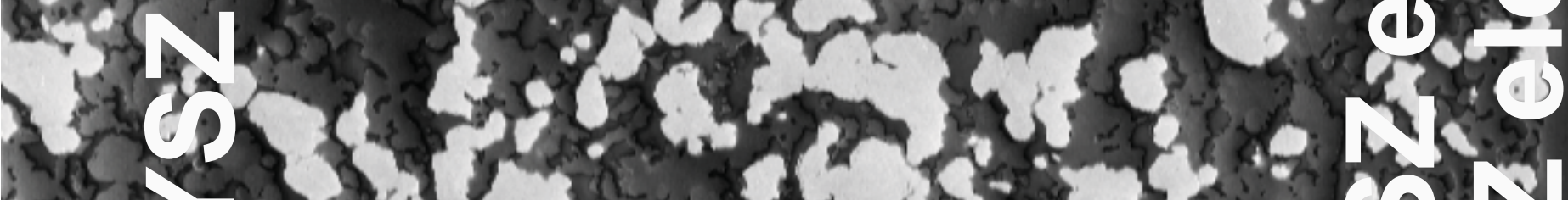

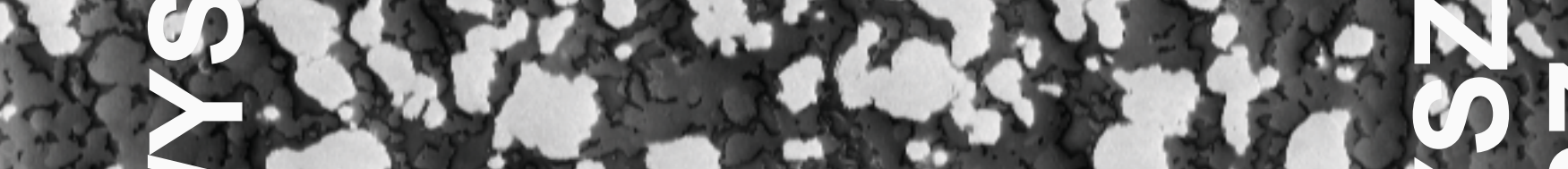

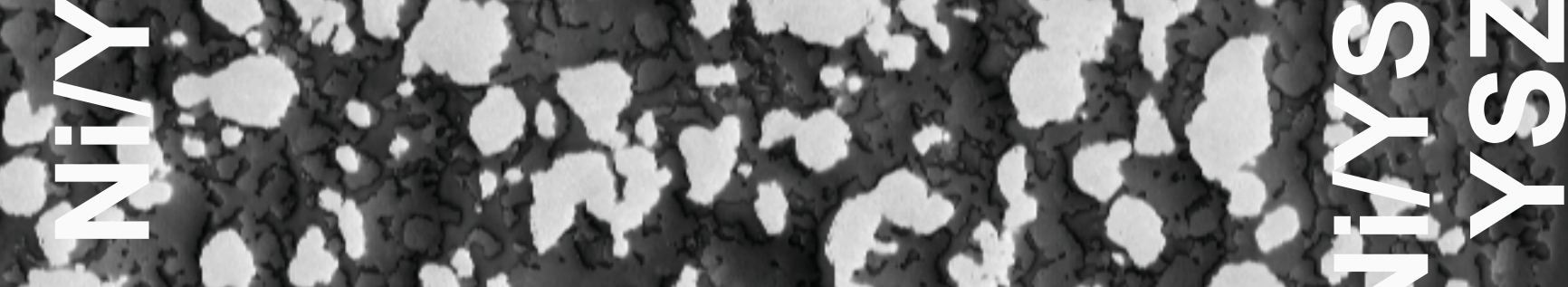

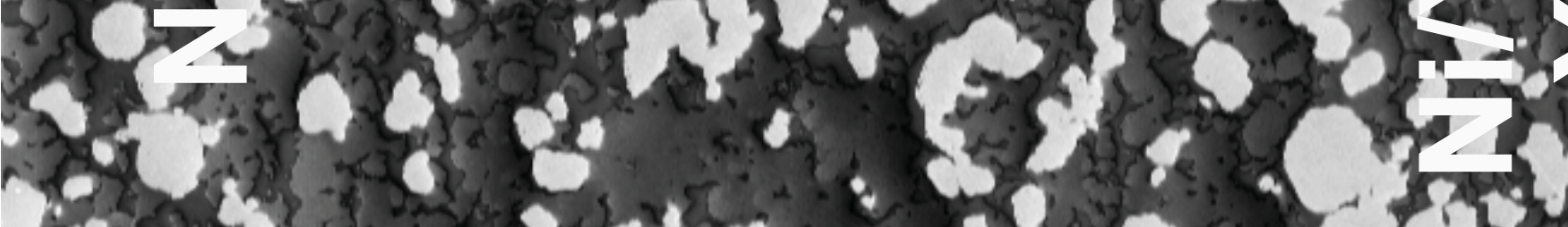

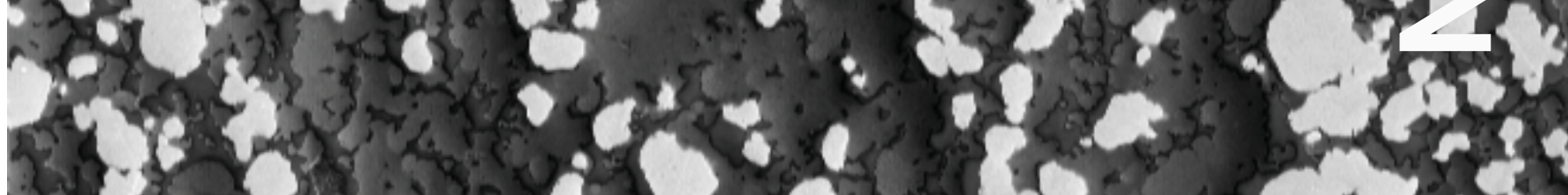

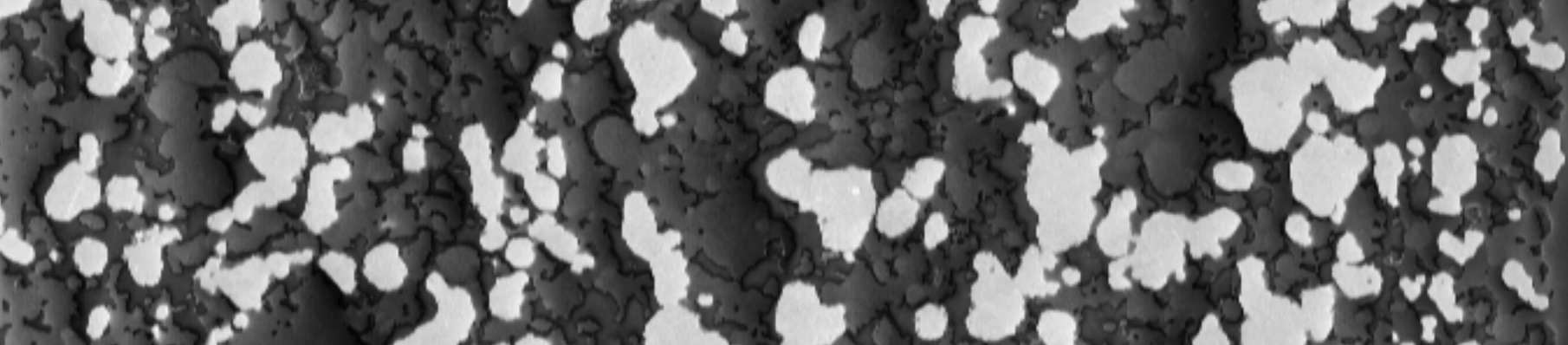

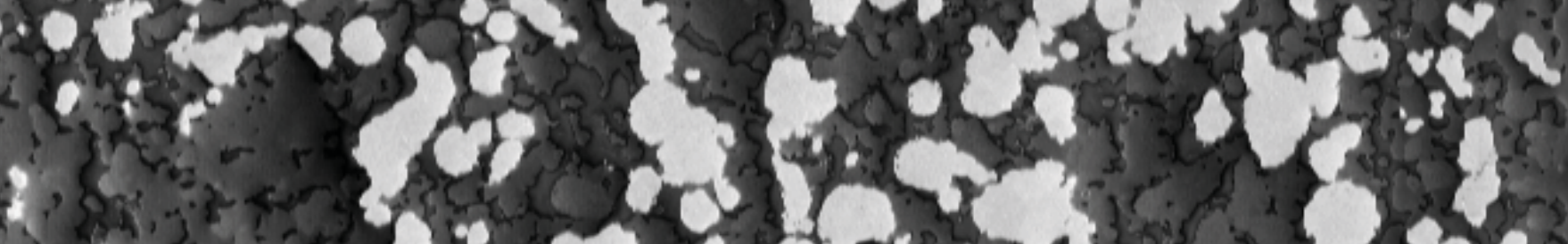

(3)

c.

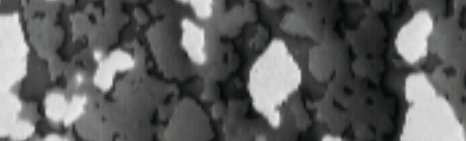
$10 \cos x$

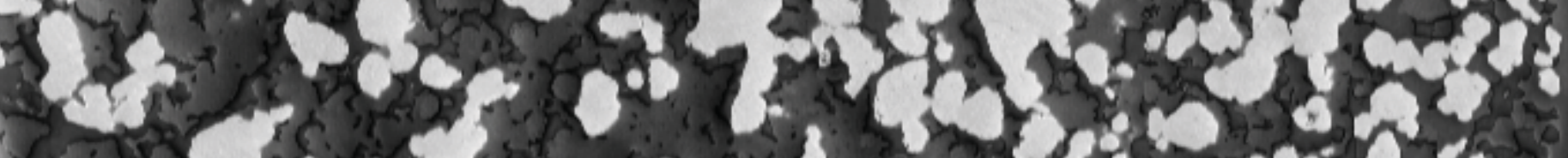

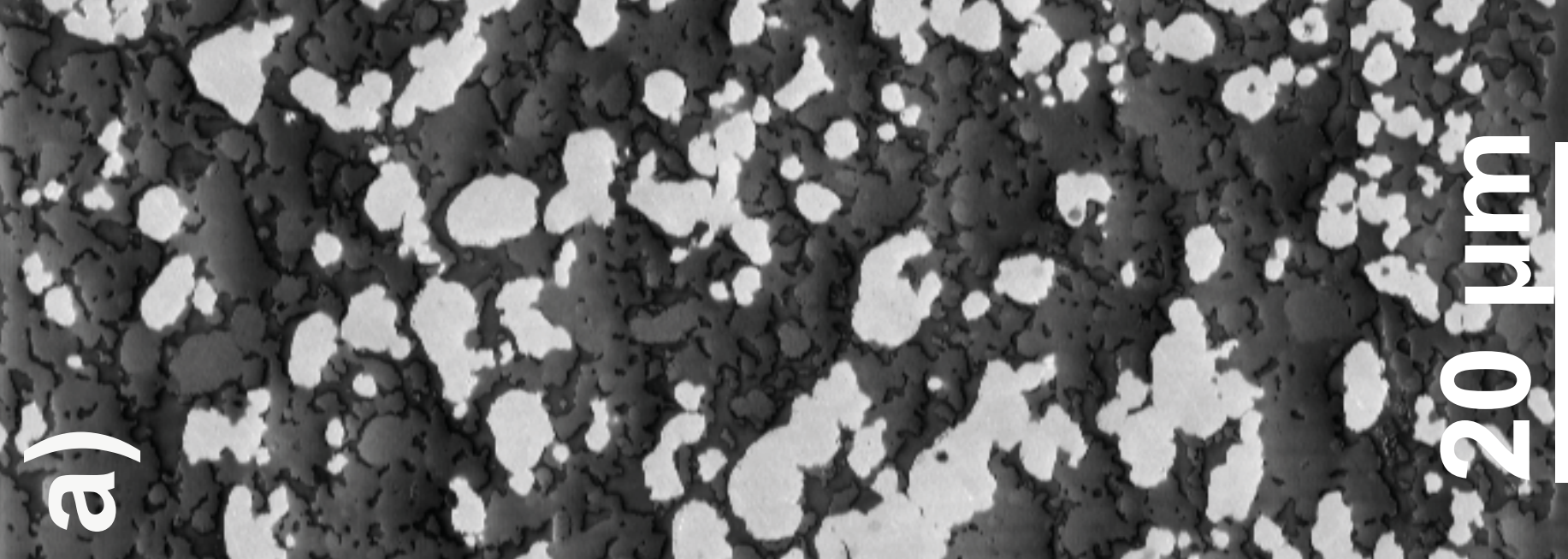


crec anta

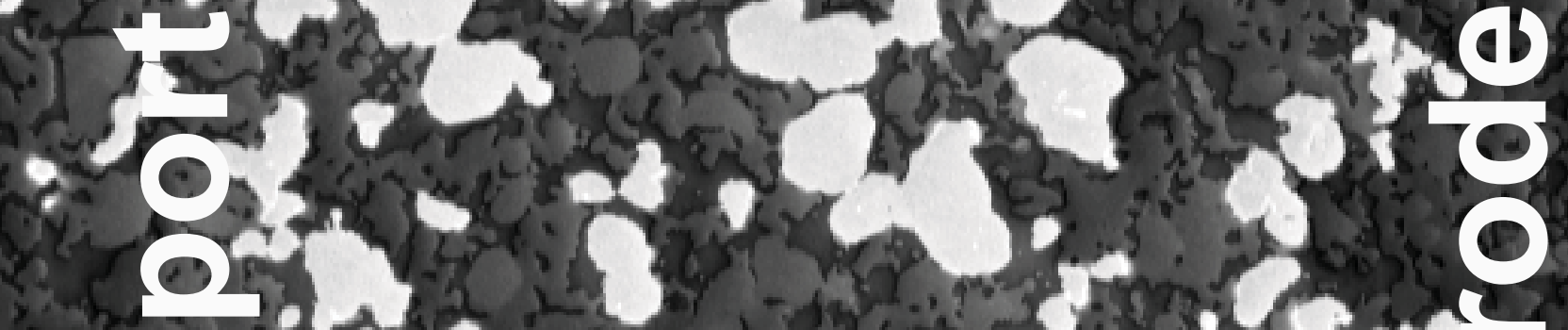

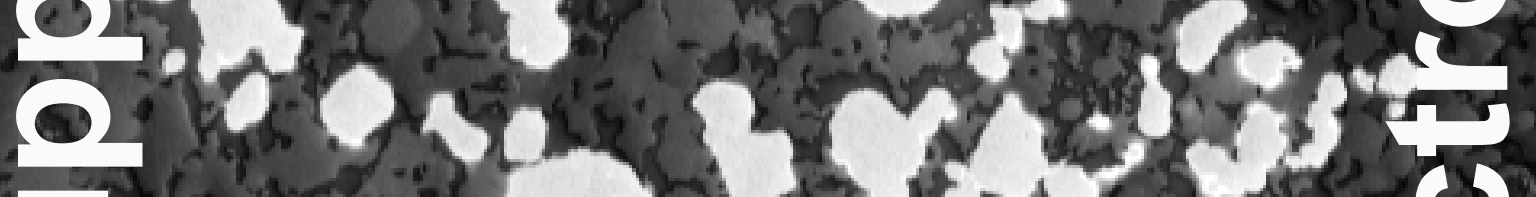

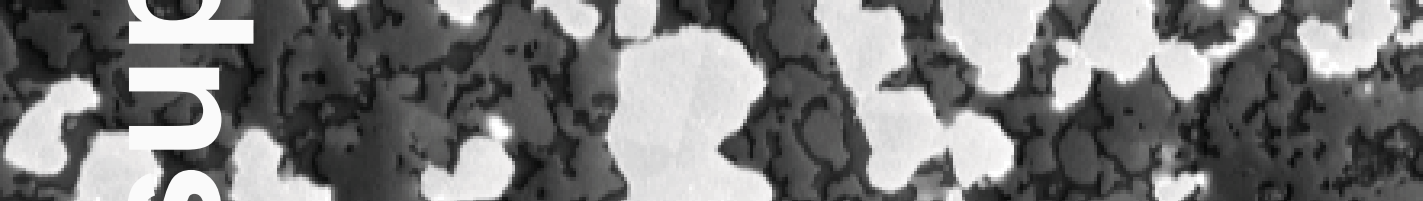
ron 3 sind

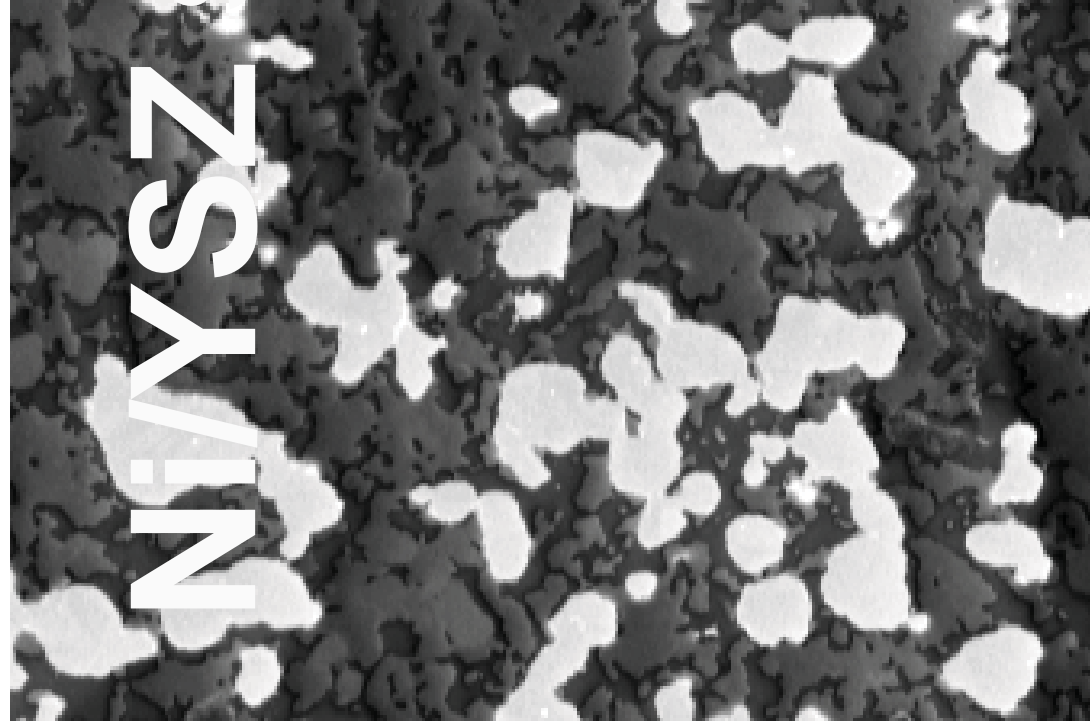

3

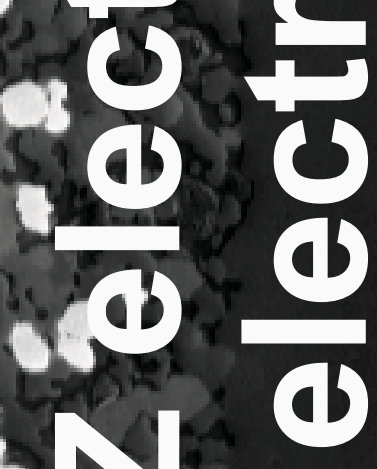

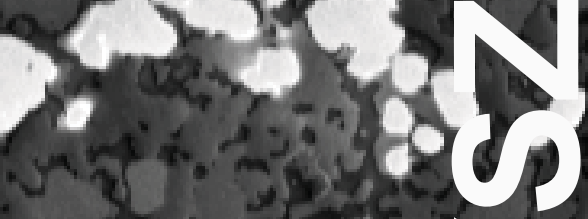

N

Co

$15 \mathrm{CO}^{3}$

25 ob 30 on

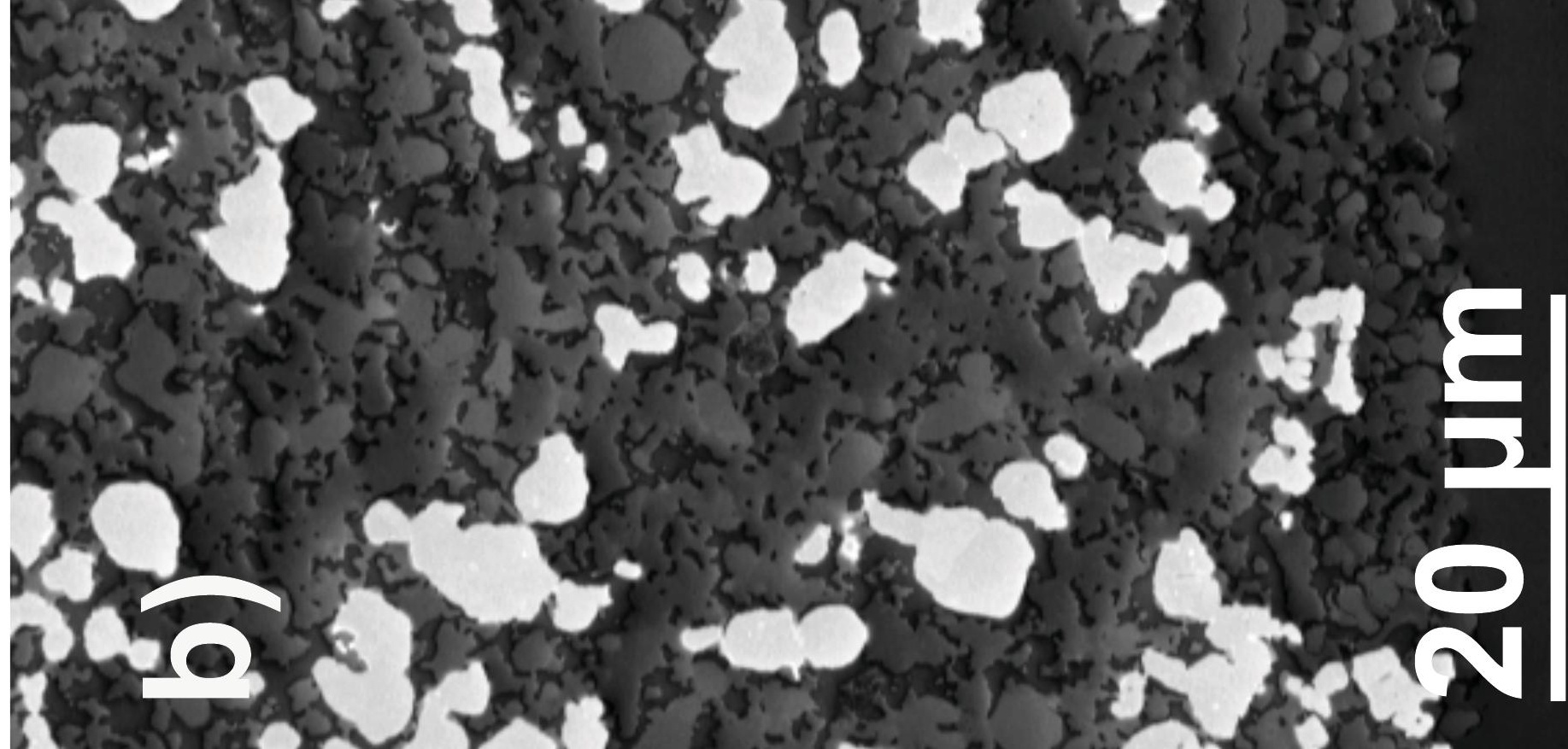




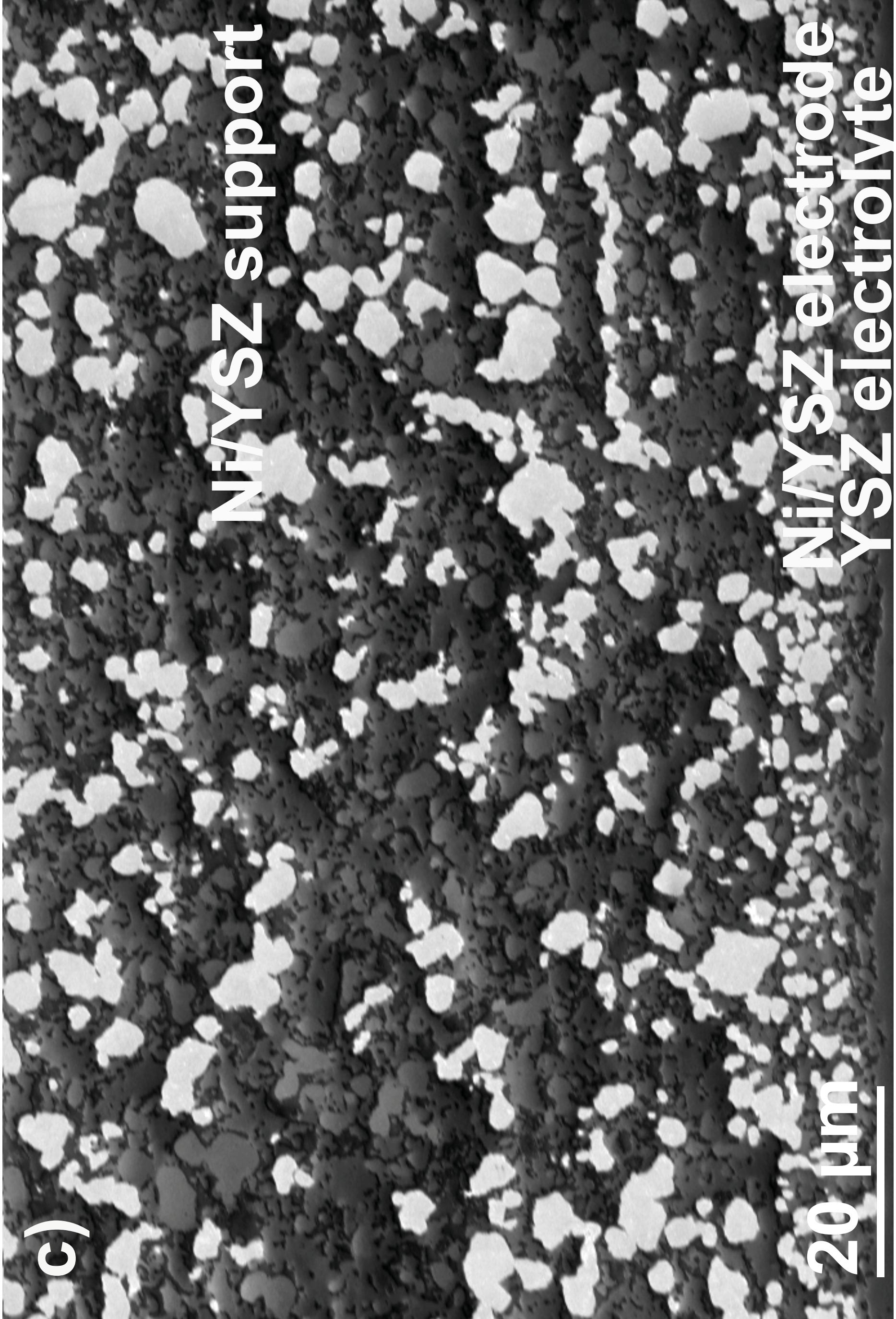


$1+2^{\circ} \mathrm{o}=$

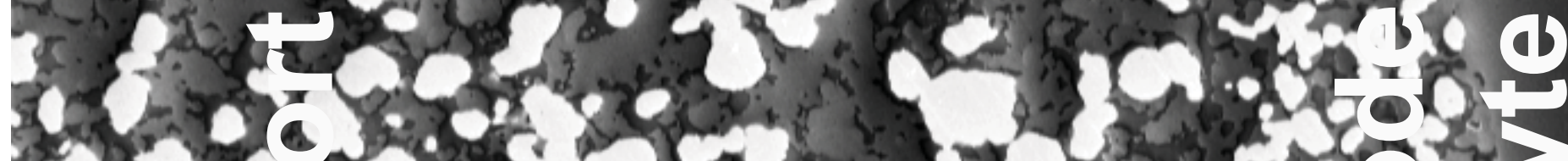
L.2.

s

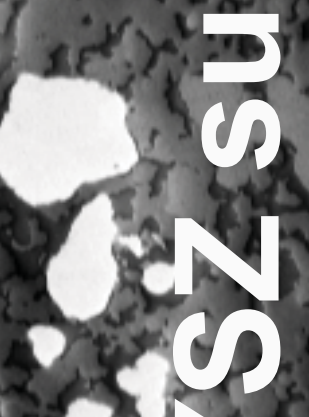

bisto

-

2. -10

che

$x^{2} 5^{5}=$ 1010 abto

$1 \rightarrow \frac{1}{4}$

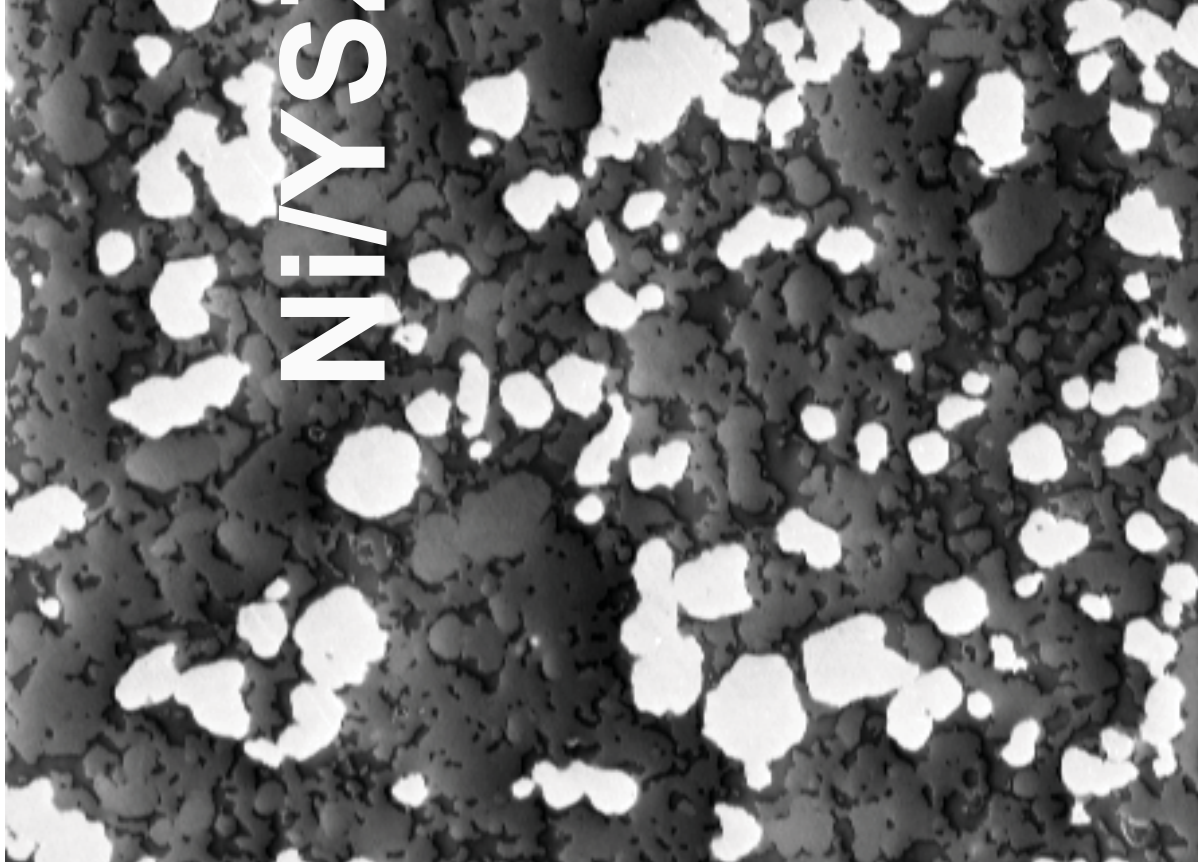

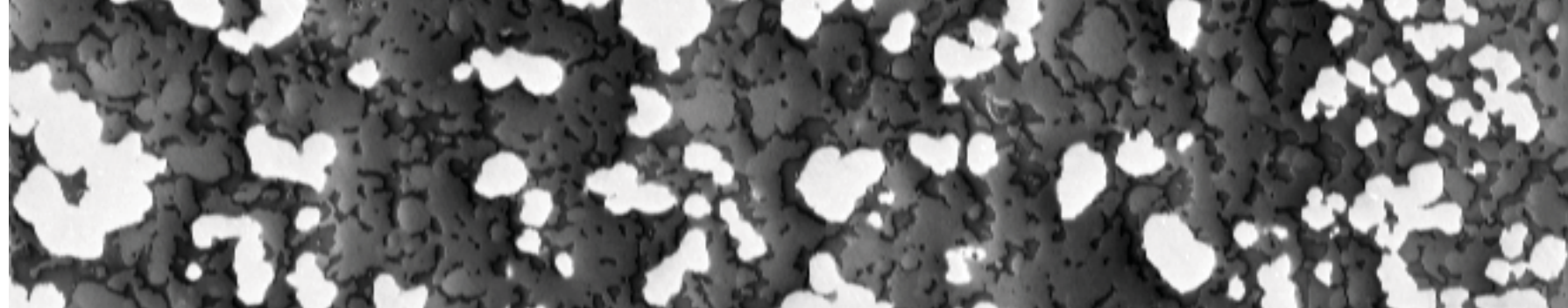
4800 (1). homets itaris? ( 125

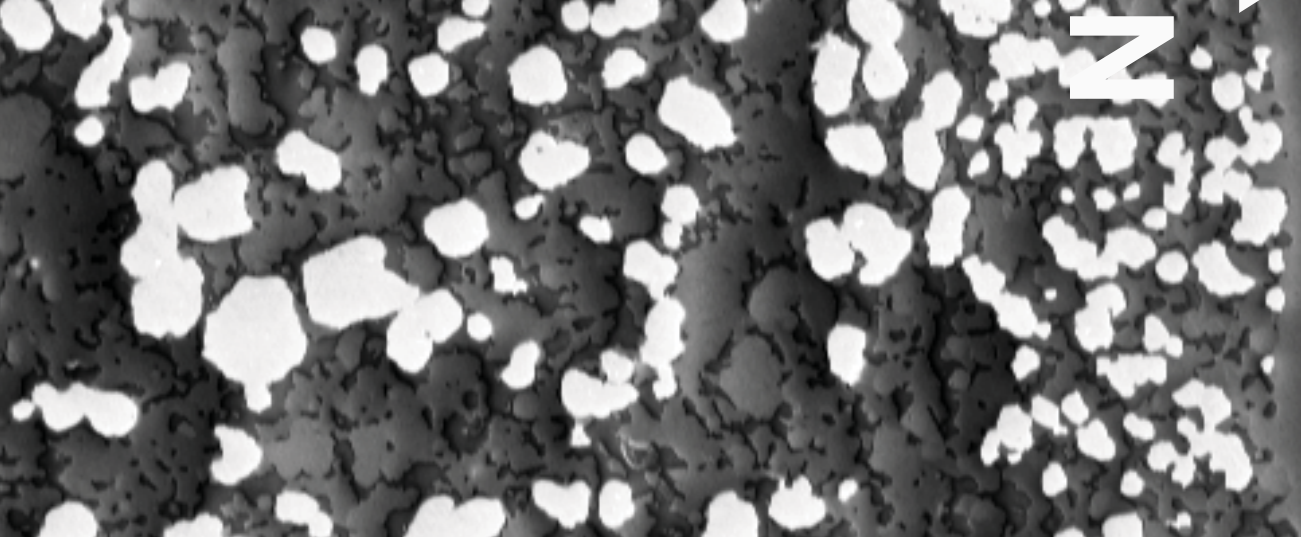

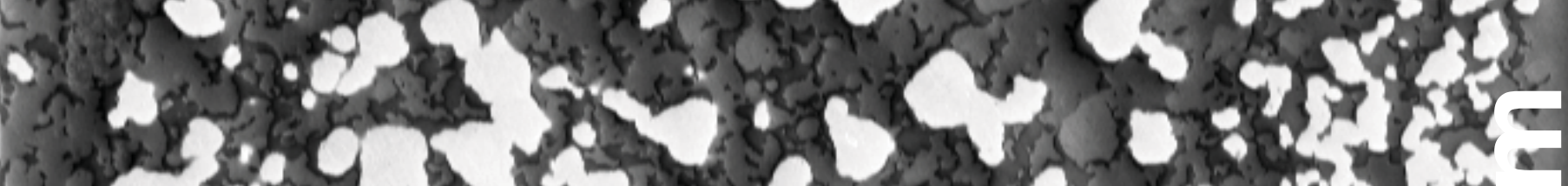

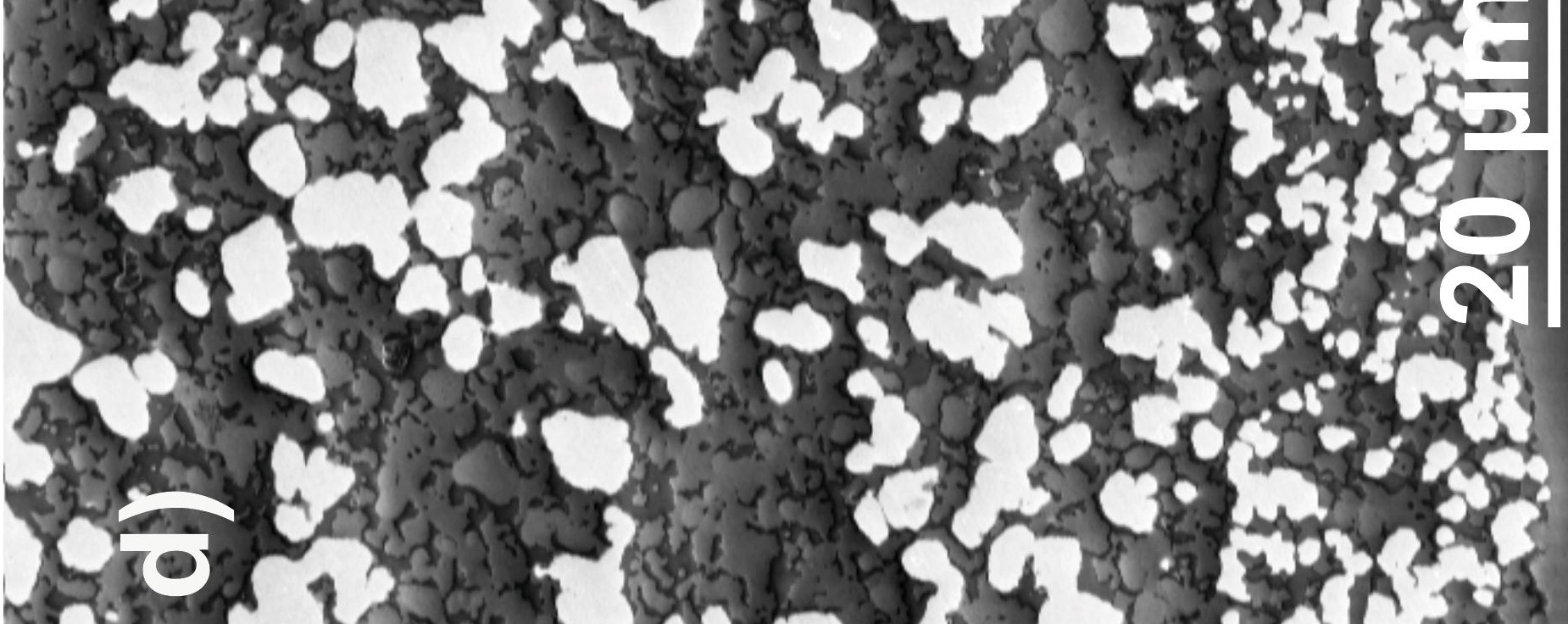




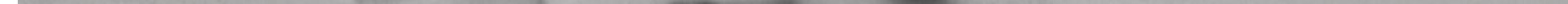




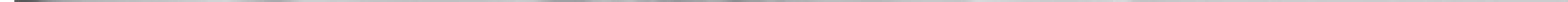




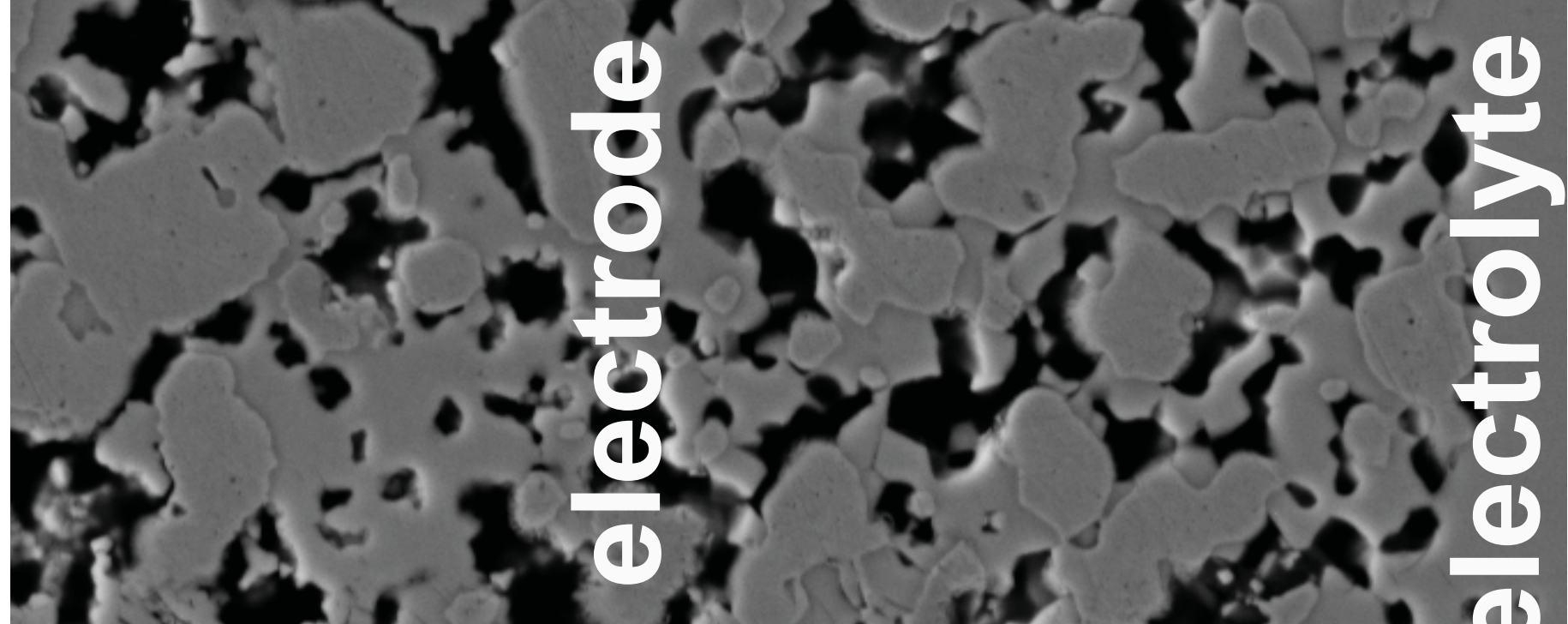

ises Nm ysom.

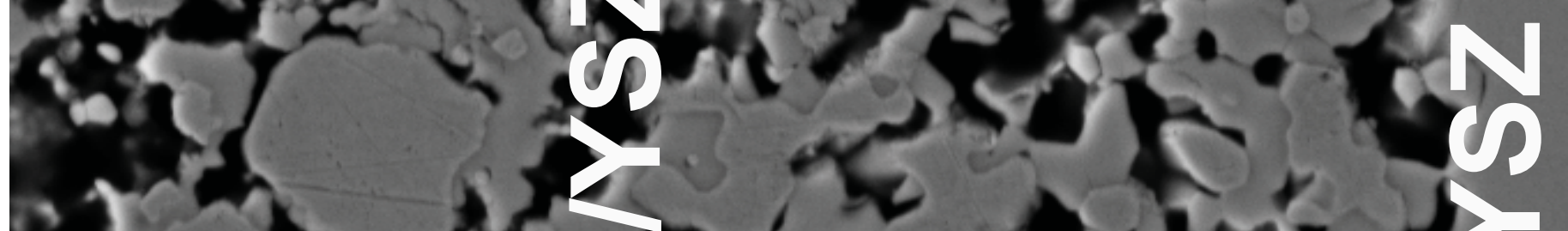

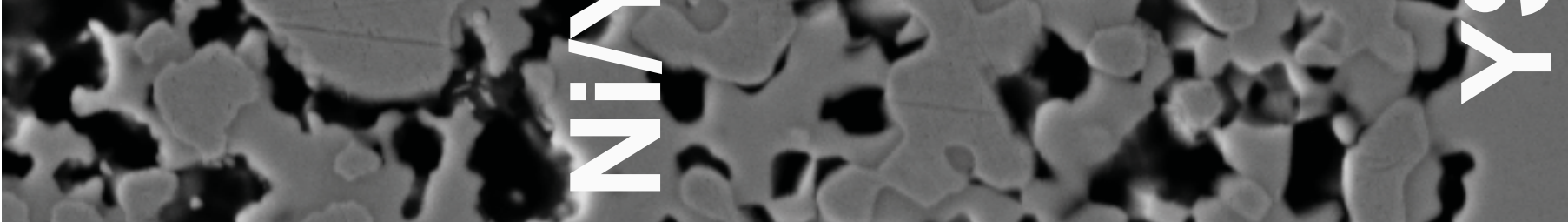

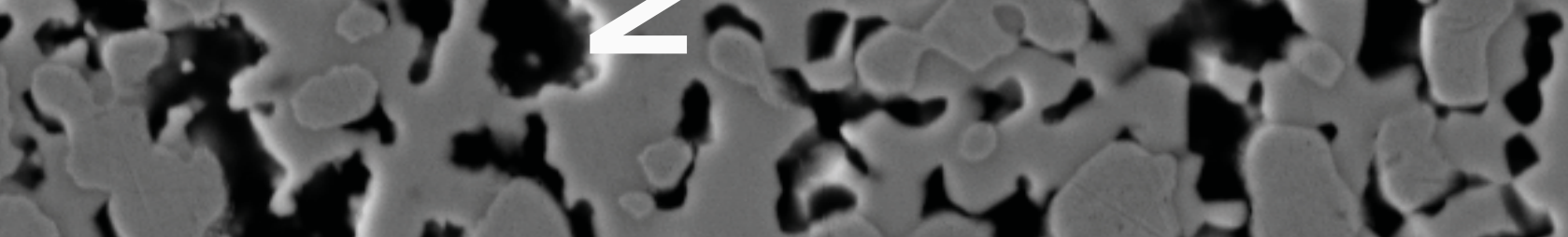

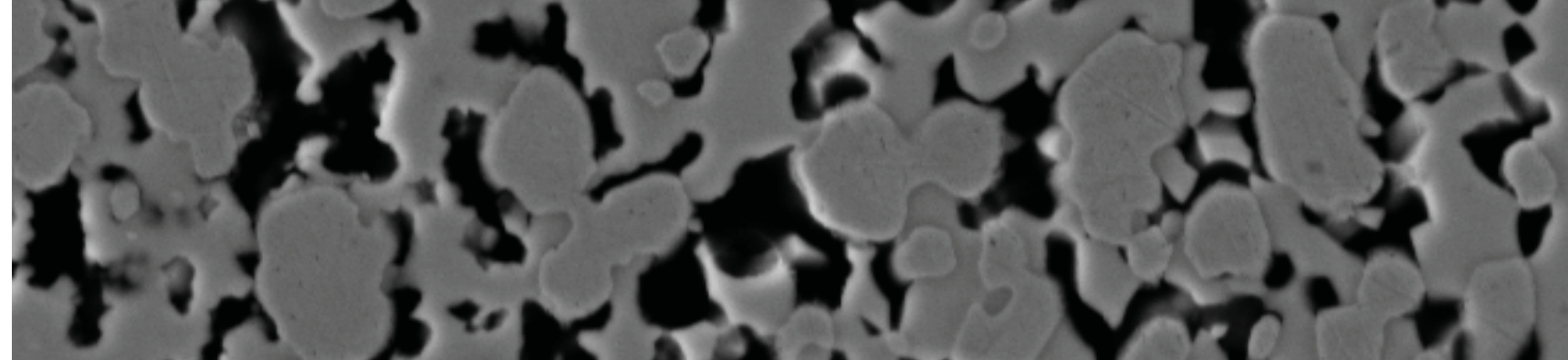

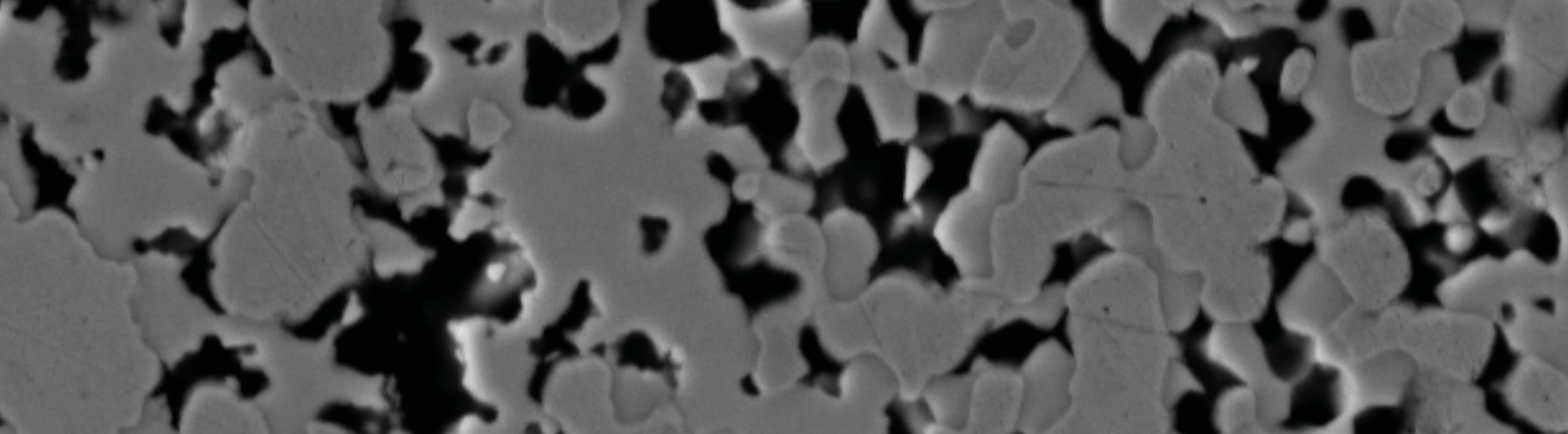

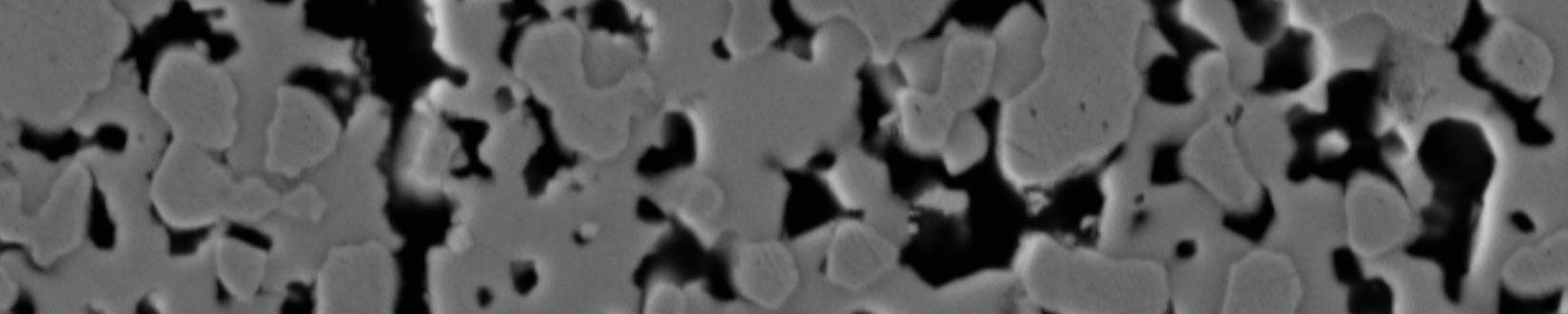
$\therefore \therefore$ l. 1001

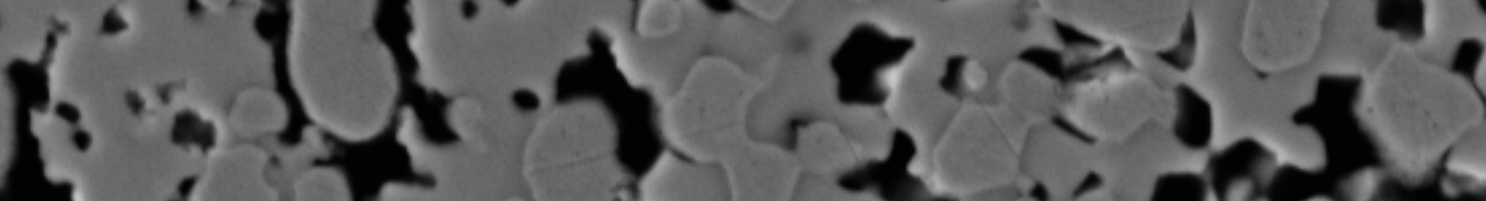

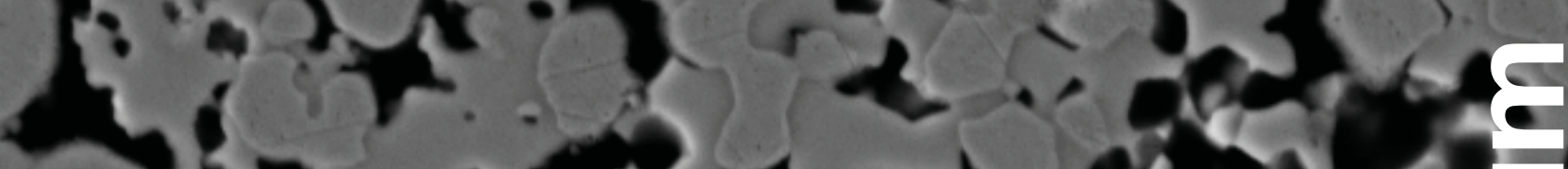

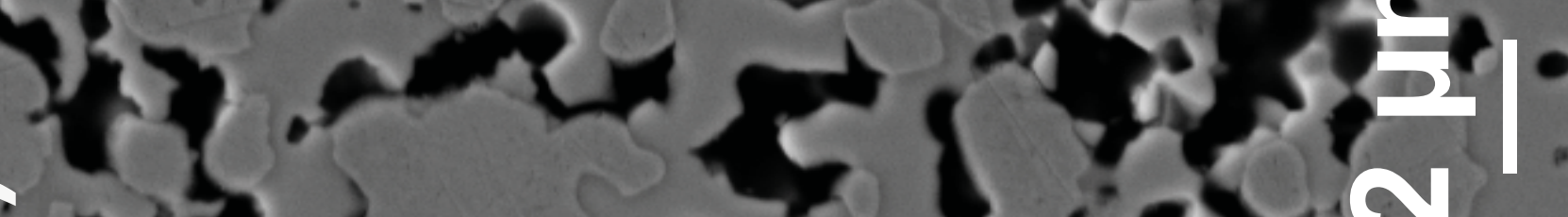
$0 \rightarrow 1 . \quad+$ a d r $30+3,4$ 
- r ler tedo

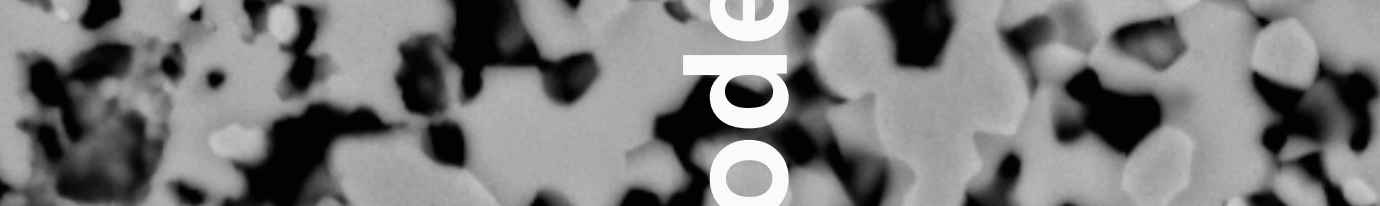

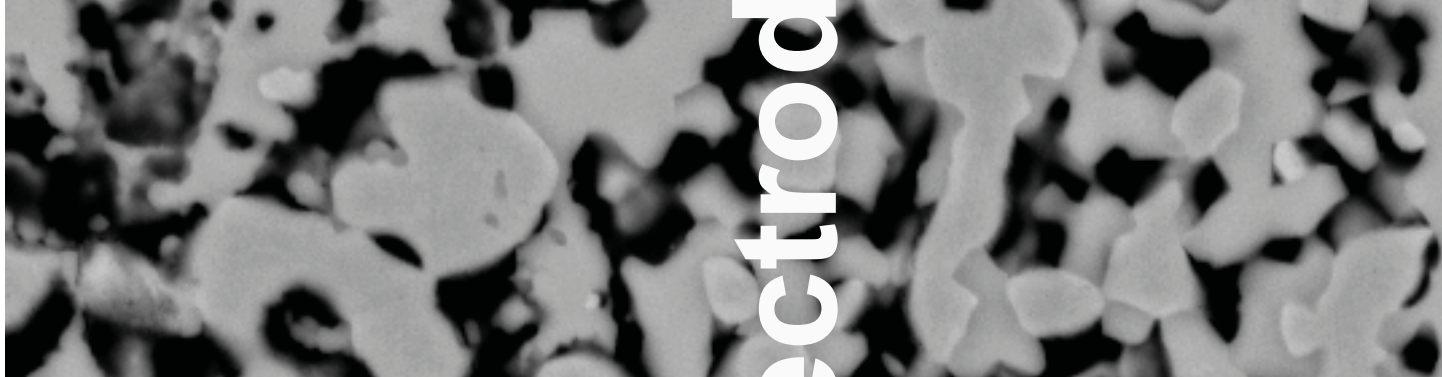

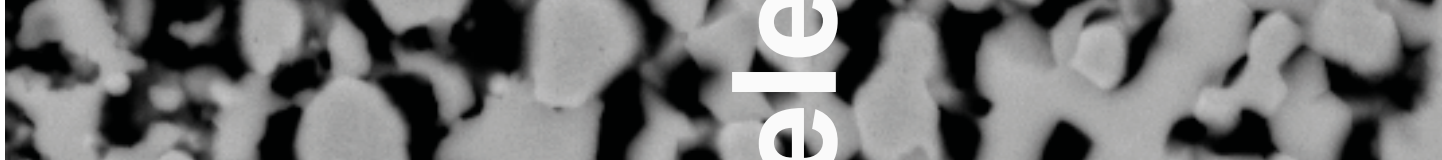

$25<200125$

4 का का नो $\sum_{i}$

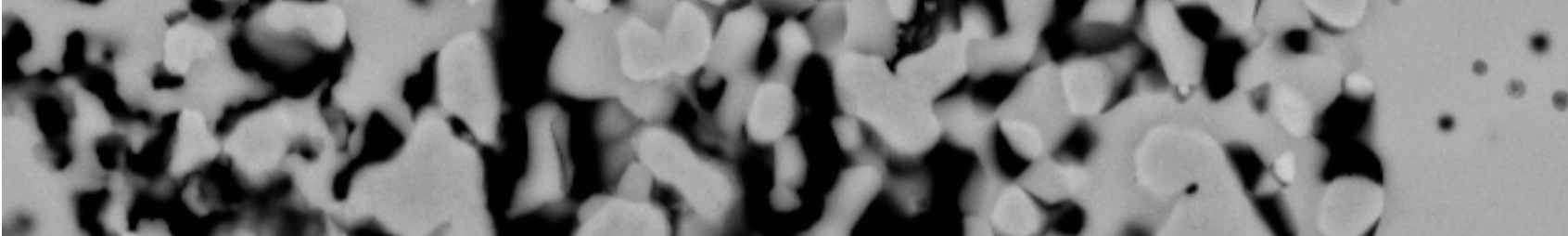

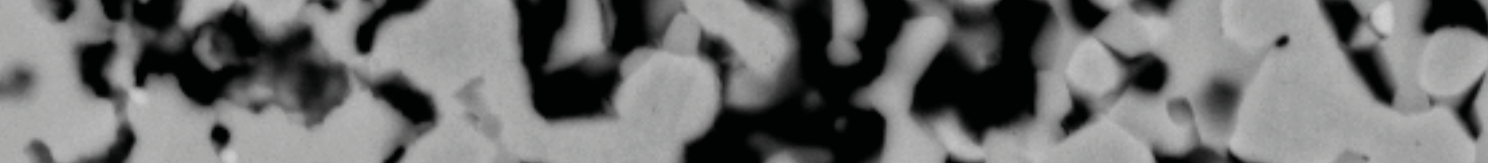

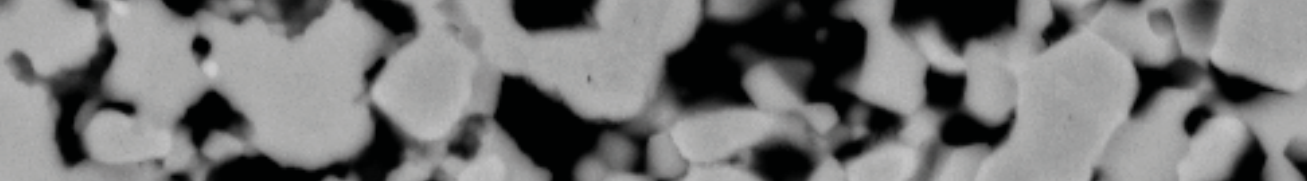

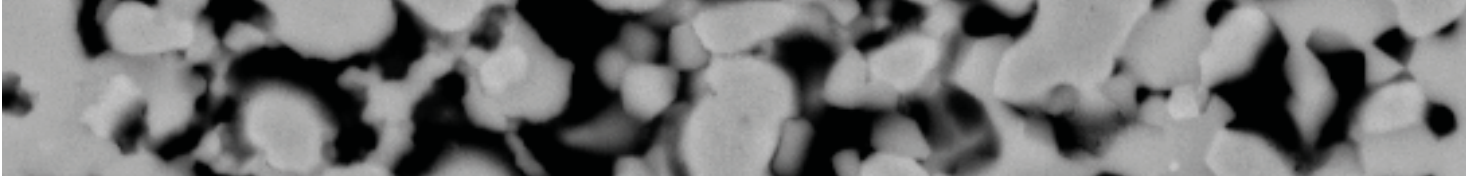

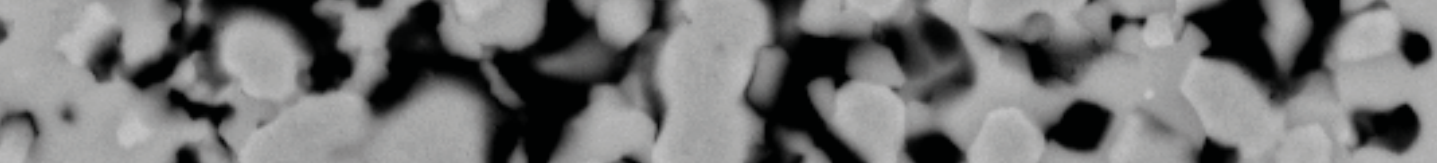
(S) (2)

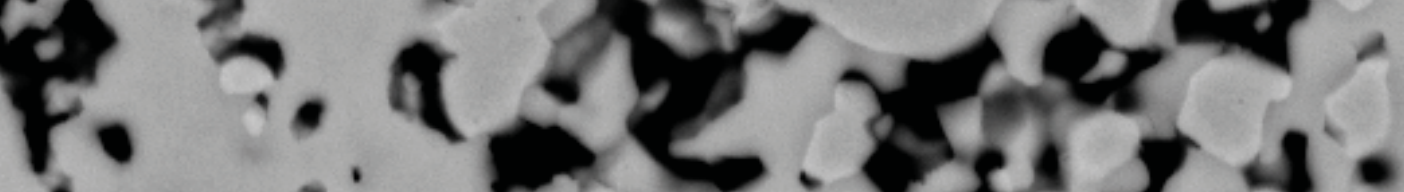
$\therefore$ a 324. \% $\rightarrow$ - $1=12$ (1) i)

23

(b)

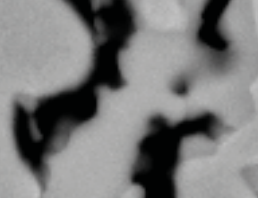

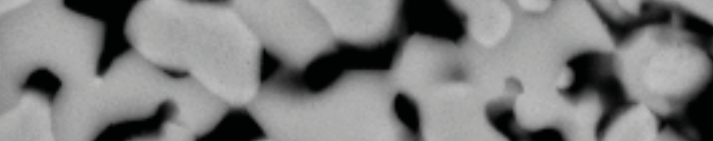
cats? a $7=1,6 \mathrm{ri}$

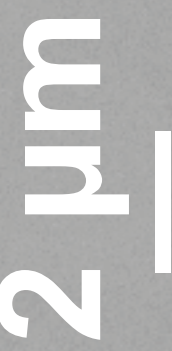




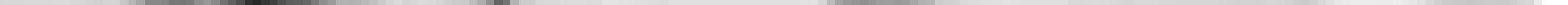




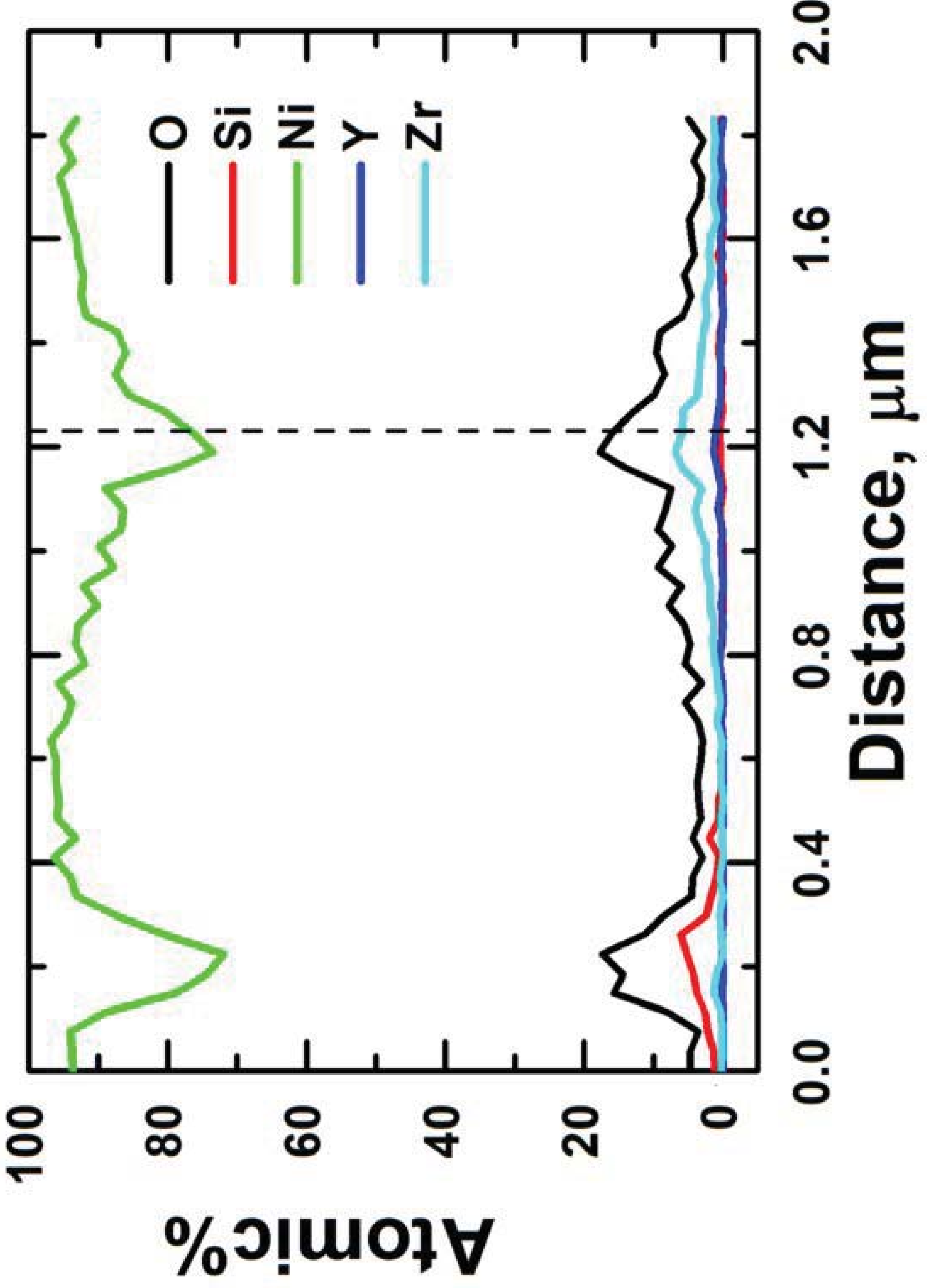



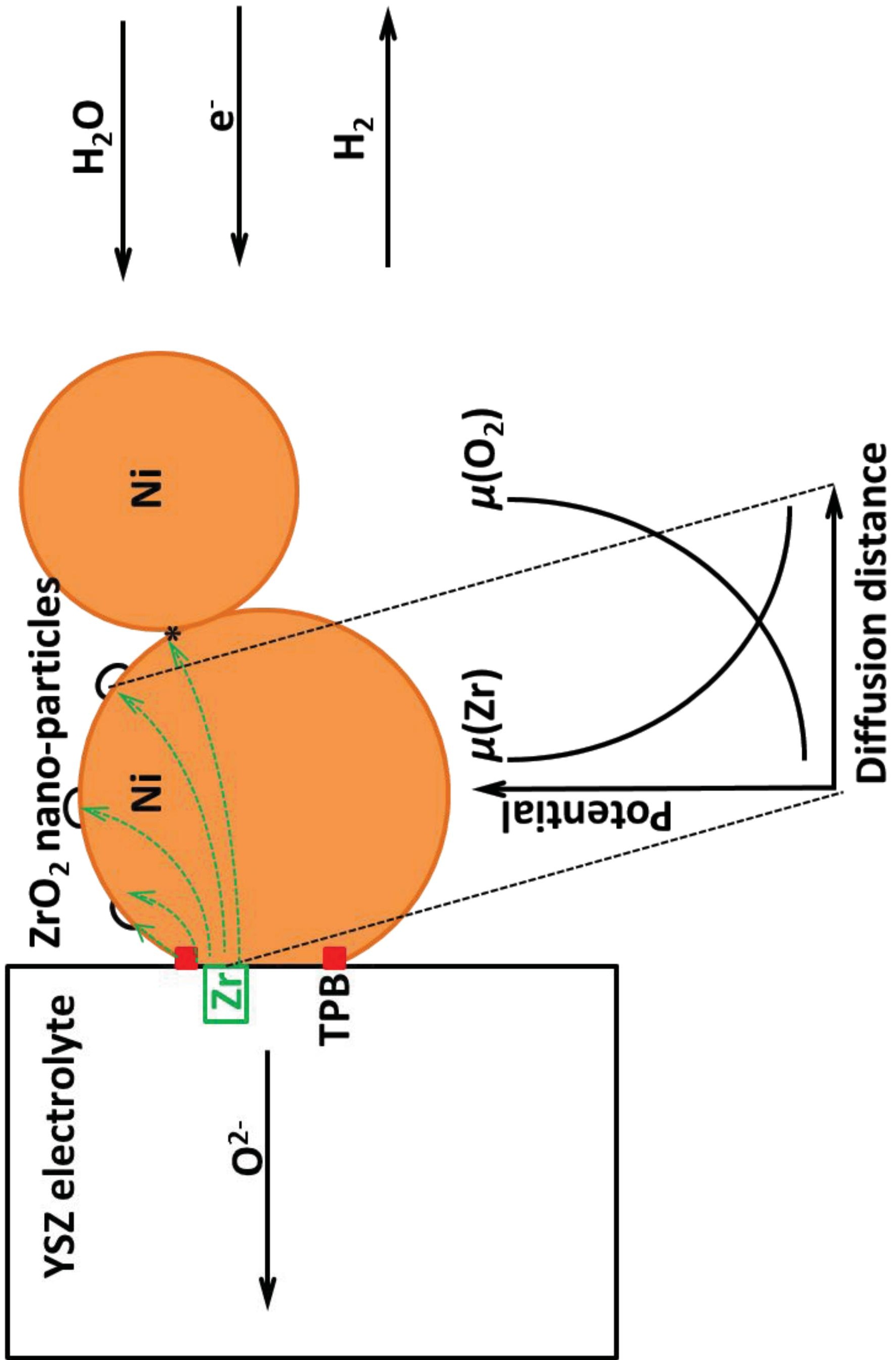


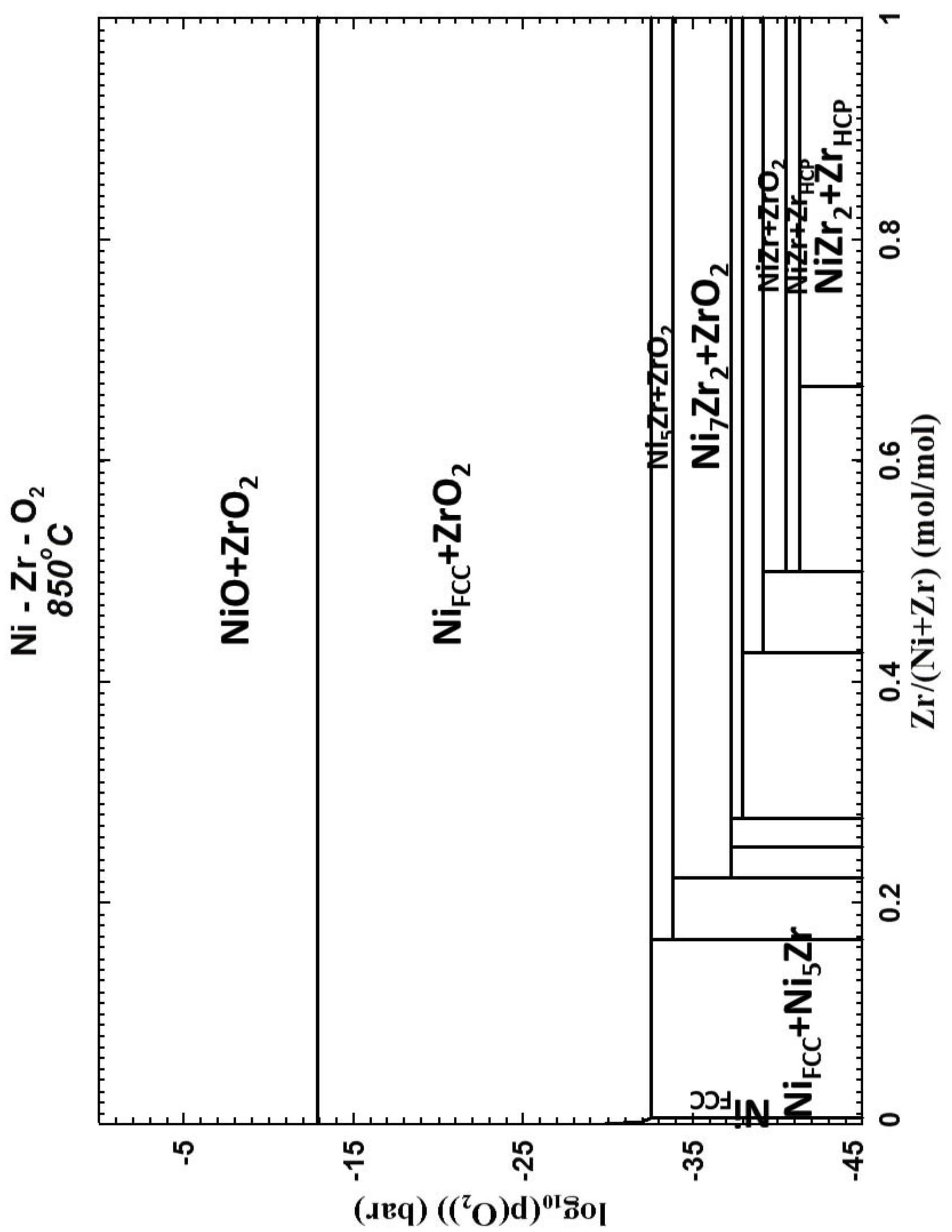




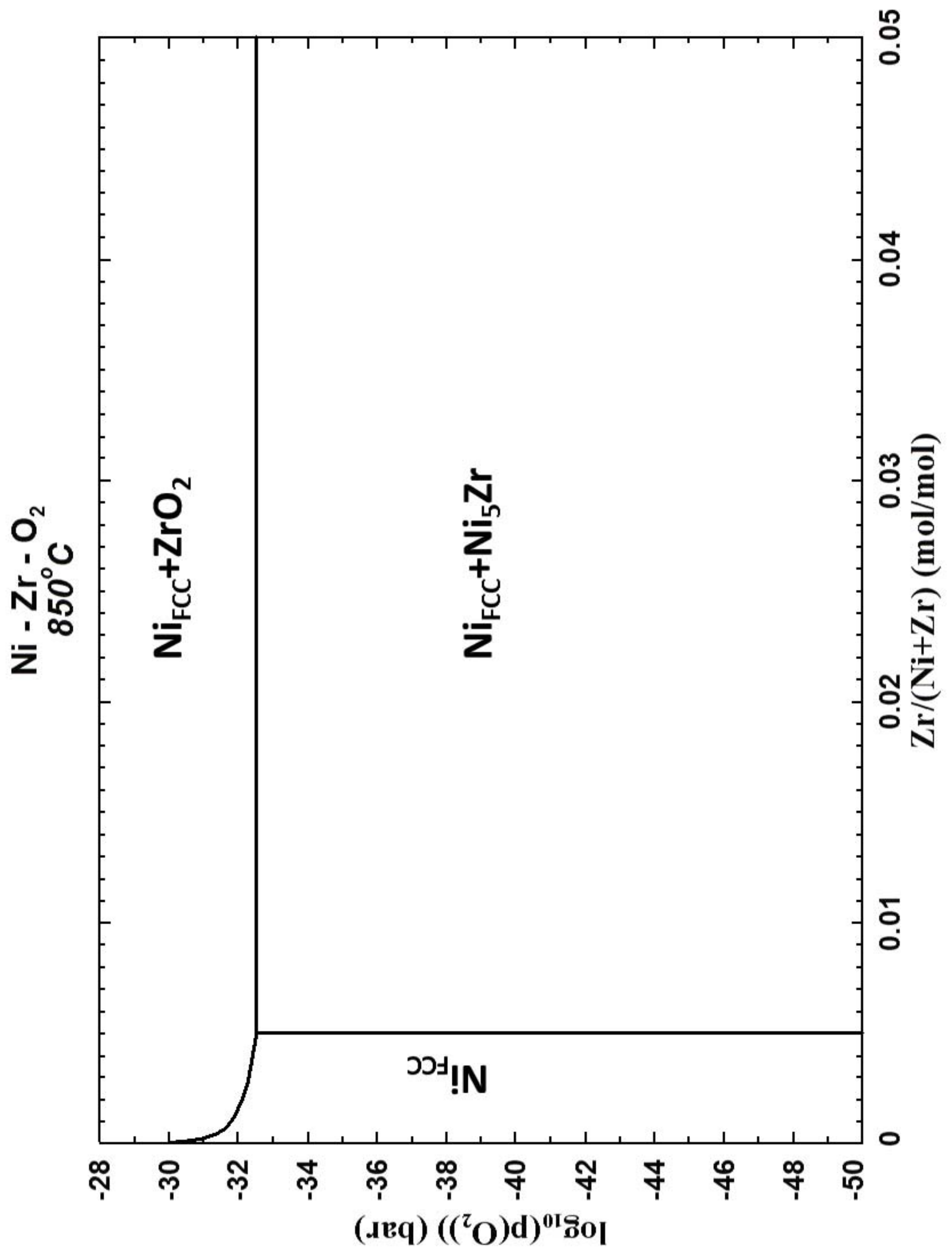




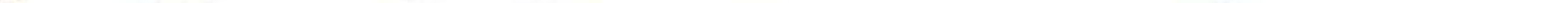




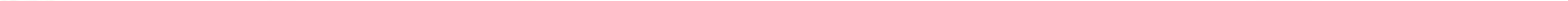

